\title{
ACPD
}

\section{High-resolution atmospheric water vapor measurements with a scanning differential absorption lidar}

\section{F. Späth, A. Behrendt, S. K. Muppa, S. Metzendorf, A. Riede, and V. Wulfmeyer}

University of Hohenheim, Institute of Physics and Meteorology, Garbenstr. 30, 70599

Stuttgart, Germany

Received: 22 July 2014 - Accepted: 16 September 2014 - Published: 21 November 2014

Correspondence to: F. Späth (f.spaeth@uni-hohenheim.de)

Published by Copernicus Publications on behalf of the European Geosciences Union.

High-resolution atmospheric water vapor measurements with a scanning DIAL

F. Späth et al.

Title Page

Abstract

Introduction

Conclusions

References

Tables

Figures

14

4

Back

Close

Full Screen / Esc

Printer-friendly Version

Interactive Discussion 


\section{Abstract}

The scanning differential absorption lidar (DIAL) of the University of Hohenheim $(\mathrm{UHOH})$ is presented. The $\mathrm{UHOH}$ DIAL is equipped with an injection-seeded frequency-stabilized high-power Ti:sapphire laser operated at $818 \mathrm{~nm}$ with a repeti-

5 tion rate of $250 \mathrm{~Hz}$. A scanning transceiver unit with a $80 \mathrm{~cm}$ primary mirror receives the atmospheric backscatter signals. The system is capable of water vapor measurements with temporal resolutions of a few seconds and a range resolution between 30 and $300 \mathrm{~m}$ at daytime. It allows to investigate surface-vegetation-atmosphere exchange processes with high resolution. In this paper, we present the design of the instrument and illustrate its performance with recent water vapor measurements taken in Stuttgart-Hohenheim and in the frame of the $\mathrm{HD}(\mathrm{CP})^{2}$ Observational Prototype Experiment (HOPE). HOPE was located near research center Jülich, in western Germany, in spring 2013 as part of the project "High Definition of Clouds and Precipitation for advancing Climate Prediction" $\left(\mathrm{HD}(\mathrm{CP})^{2}\right)$. Scanning measurements reveal the 3-

dimensional structures of the water vapor field. The influence of uncertainties within the calculation of the absorption cross-section at wavelengths around $818 \mathrm{~nm}$ for the WV retrieval is discussed. Radiosonde intercomparisons show a very small bias between the instruments of only $(-0.04 \pm 0.11) \mathrm{g} \mathrm{m}^{-3}$ or $(-1.0 \pm 2.3) \%$ in the height range of 0.5 to $3 \mathrm{~km}$.

\section{Introduction}

Water vapor is the most important greenhouse gas and plays a key role in Earth's weather and climate. Accurate observations of water vapor (WV) in the lower troposphere from the surface to the entrainment zone at the top of the convective atmospheric boundary layer ( $\mathrm{ABL}$ ) are essential for improving weather forecasting (e.g., Crook 1996; Dierer et al., 2009) and reanalyses (Bengtsson et al., 2004). Furthermore, better parameterizations of land-surface and turbulent transport processes in the ABL

High-resolution atmospheric water vapor measurements with a scanning DIAL

F. Späth et al.

Title Page

Abstract

14

$\Delta$

4 
are essential for improved regional climate projections (Warrach-Sagi et al., 2013; Kotlarski et al., 2014). Lidar with its ability to measure water vapor with high temporal and spatial resolution and high accuracy has the means to investigate the relevant atmospheric processes for these improvements.

For sounding water vapor with lidar, the Raman technique (e.g., Melfi et al., 1969; Whiteman et al., 1992; Behrendt et al., 2002; Hammann et al., 2014) or the differential absorption lidar (DIAL) technique (Schotland, 1974; Browell et al., 1979; Wulfmeyer and Walther, 2001a, b) can be applied. The water vapor DIAL of University of Hohenheim $(\mathrm{UHOH})$ is a ground-based instrument which allows for 3-dimensional measure10 ments of water vapor fields in the atmospheric boundary layer with high resolution and accuracy (Behrendt et al., 2009, 2011, 2012). For instance in the COPS field campaign 2007 (Wulfmeyer et al., 2008, 2011; Behrendt et al., 2013), the UHOH DIAL demonstrated its high spatial and temporal resolution and range for studying the preconvective environment (Behrendt et al., 2011) and convection initiation (Corsmeier et al., 2011) as well as its high accuracy in comparison to other in-situ sensors and remote sensing systems (Bhawar et al., 2011). Furthermore, its scanning capability was shown within the DFG Transregio 32 project in 2009 (Behrendt et al., 2009) for studying the performance of turbulence parameterizations in the convective atmospheric boundary layer (Wulfmeyer et al., 2014a).

In spring 2013, the UHOH DIAL was operated within the project "High Definition of Clouds and Precipitation for advancing Climate Prediction" $\left(\mathrm{HD}(C P)^{2}\right) . \mathrm{HD}(C P)^{2}$ was initiated for improving the understanding of turbulent and mesoscale processes resulting in formation of clouds and precipitation. According to Stevens and Bony (2013), advanced formulation of these processes in climate models is critical for improving the 25 predictions. Therefore in April and May 2013 the "HD(CP) ${ }^{2}$ Observation Prototype Experiment" (HOPE) was organized near research center Jülich, in western Germany. Goal of the experiment was to produce a dataset of atmospheric measurements for a model evaluation at the scale of the model simulations. The new $\operatorname{HD}(C P)^{2}$ model shall
ACPD

14, 29057-29099, 2014

High-resolution

atmospheric water vapor measurements with a scanning DIAL

F. Späth et al.

Title Page

Abstract Introduction

Conclusions

References

Tables

Figures

14

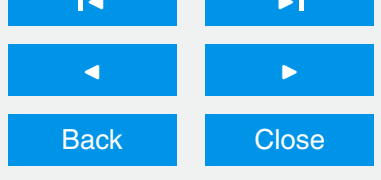

Full Screen / Esc

Printer-friendly Version

Interactive Discussion 
provide simulations with a horizontal grid spacing of $100 \mathrm{~m}$ over domains of $100 \times 100$ up to $1000 \mathrm{~km} \times 1000 \mathrm{~km}$.

For HOPE, three supersites were set up in a triangular configuration with distances of about $4 \mathrm{~km}$ between each other. All these sites were equipped with in-situ and re5 mote sensing instruments to measure atmospheric parameters. With the different instruments, the temporal and spatial heterogeneity of the convective boundary layer $(\mathrm{CBL})$ was investigated concerning $\mathrm{WV}$, temperature, and wind fields as well as the distribution of aerosol particles and clouds. The high-resolution fields of the measured thermodynamic parameters are also used to derive higher-order moments of turbulent 10 fluctuations (Muppa et al., 2014; Behrendt et al., 2014) as well as sensible and latent heat fluxes (Wulfmeyer et al., 2014b). The results shall contribute to an improved understanding of the relations between surface properties and boundary layer characteristics, shallow cumulus convection, as well as convection initiation.

The UHOH DIAL was located at the HOPE Supersite near Hambach $15\left(50^{\circ} 53^{\prime} 50.56^{\prime \prime} \mathrm{N}, 6^{\circ} 27^{\prime} 50.39^{\prime \prime} \mathrm{E}\right)$. At the same site with the UHOH DIAL, the UHOH Rotational Raman Lidar (RRL) (Radlach et al., 2008; Hammann et al., 2014) took measurements of temperature and the KITcube (Kalthoff et al., 2013) observed - among others - the surface energy balance (Kalthoff et al., 2006; Kraus et al., 2010) and wind velocity with scanning Doppler lidar (Träumner, 2010). The UHOH DIAL provided measurements of more than $180 \mathrm{~h}$ on 18 intensive observation periods (IOPs) in different scanning modes.

In the following, we explain the DIAL technique and describe sensitivity studies of the water-vapor absorption cross-section in Sect. 2. In Sect. 3, the setup of the UHOH DIAL is presented. Results of vertical measurements from Stuttgart-Hohenheim and scanning measurements from the HOPE campaign are shown in Sect. 4. Finally we close with a summary.
ACPD

14, 29057-29099, 2014

High-resolution

atmospheric water vapor measurements with a scanning DIAL

F. Späth et al.

Title Page

Abstract

Introduction

Conclusions

References

Tables

Figures

14

$\rightarrow 1$

4

Back

Close

Full Screen / Esc

Printer-friendly Version

Interactive Discussion 


\section{DIAL technique}

\subsection{Theory}

DIAL measures the number density of a trace gas, e.g. water vapor, with two backscatter lidar signals. One signal is tuned to a wavelength with high absorption of the trace 5 gas $\left(S_{\text {on }}(r)\right.$ : online signal) and the other signal to a wavelength with low absorption $\left(S_{\text {off }}(r)\right.$ : offline signal). $r$ is the range from the lidar system to the scattering volume. The exponential decrease of the intensity of a beam passing through a gas with extinction coefficient $\alpha_{\text {gas }}$ is described by Lambert-Beer's law

$S(r)=S_{0} \exp \left(-\int_{0}^{r} \alpha_{\text {gas }}(r) \mathrm{d} r\right)$

with the transmitted power $S(r)$, the initial intensity $S_{0} . \alpha_{\text {gas }}$ is related to the absorption cross-section $\sigma_{\text {gas }}$ and the number density $N_{\text {gas }}$ of the trace gas by $\alpha_{\text {gas }}(r)=$ $N_{\text {gas }}(r) \sigma_{\text {gas }}(r)$. From these two equations, one gets the Schotland approximation of the DIAL equation (Schotland 1966, 1974)

$N_{\mathrm{WV}}(r)=\frac{1}{2 \cdot \sigma_{\mathrm{eff}}(r)} \frac{\mathrm{d}}{\mathrm{d} r} \ln \frac{S_{\mathrm{on}}(r)}{S_{\mathrm{off}}(r)}$.

15 with $\sigma_{\text {eff }}(r)=\sigma_{\text {on }}(r)-\sigma_{\text {off }}(r)$ for the effective cross-section. Online and offline wavelengths should be chosen close to each other because the Rayleigh extinction coefficient, the particle extinction coefficient, and the backscatter coefficient for online and offline wavelengths cancel when taking the ratio of the signals in Eq. (2). System parameters which are constant with range $r$ cancel because of the derivation. Thus, for DIAL measurements no calibration needs to be applied but only the values of the absorption cross-sections at online and offline wavelength $\sigma_{\text {on }}$ and $\sigma_{\text {off }}$ are needed for measuring $N_{\text {gas }}$. Equation (2), however, assumes that changes of the backscatter spectrum in the considered range cells can be neglected. Otherwise, a correction

High-resolution atmospheric water vapor measurements with a scanning DIAL

F. Späth et al.

Title Page

Abstract

Introduction

Conclusions

Tables

References

Figures

14

4

Back

Full Screen / Esc

Printer-friendly Version

Interactive Discussion 
has to be applied for the Rayleigh-Doppler effect (Ansmann and Bösenberg 1987), which becomes significant at strong particle backscatter gradients. Within the analyses presented here this effect was not critical as confirmed also by comparisons with radiosoundings.

5 In the following, we concentrate on the accuracy of the determination of $\sigma_{\text {eff }}$ in Eq. (2). $\sigma_{\text {eff }}$ depends on atmospheric conditions, i.e. ambient temperature, air pressure, and humidity. These parameters are height-dependent. Due to this, $\sigma_{\text {eff }}$ depends on $r$. The calculation of $\sigma_{\text {eff }}$ in our data analysis procedure is described in more detail in Sect. 2.2.

\subsection{Water vapor absorption cross-section}

10 The water vapor number density $N_{\mathrm{Wv}}(z)$ varies within several orders of magnitude in the Earth's atmosphere. Also temperature $T(z)$ and air pressure $p(z)$ change with height and time. These three parameters influence the water-vapor absorption crosssection $\sigma_{\mathrm{wV}}\left(\lambda, T, p, N_{\mathrm{wV}}\right)$ at a certain wavelength $\lambda$. In this section we are using wave numbers $\tilde{v}=\lambda^{-1}$ in $\mathrm{cm}^{-1}$ instead of wavelengths as it is usual in spectroscopy. All given wave numbers and wavelength throughout this paper are based on the vacuum wavelength.

$\sigma_{\mathrm{WV}}$ is calculated as a sum over broadened absorption lines at a specific wave number $\tilde{v}_{\mathrm{WV}, k}$. The absorption cross-section $\sigma_{k}$ of each absorption line $k$ can be described by the line strength $I_{k}$ and by the line shape $V_{k}$ according to

$20 \sigma_{k}\left(\tilde{v}, T, p, N_{\mathrm{WV}}\right)=I_{k}(T) V_{k}\left(T, p, N_{\mathrm{WV}}\right)$.

The line strength $I_{k}$ depends on the temperature $T$ and the ground-state energy $E_{\mathrm{B}, k}$ at the standard temperature $T_{0}$ and follows the equation

$I_{k}(T)=I_{k}\left(T_{0}\right)\left(\frac{T_{0}}{T(z)}\right)^{1.5} \exp \left(\frac{E_{\mathrm{B}, k}}{k_{\mathrm{B}}}\left(\frac{1}{T_{0}}-\frac{1}{T(z)}\right)\right)$

with $k_{\mathrm{B}}$ for the Boltzmann constant. The absorption lines are broadened due to pres-

sure and Doppler effects. Additionally the absorption line peaks are shifted to larger
14, 29057-29099, 2014

High-resolution

atmospheric water

vapor measurements

with a scanning DIAL

F. Späth et al.

Title Page

Abstract

Introduction

Conclusions

References

Tables

Figures

14

$\Delta$

4

Back

Close

Full Screen / Esc

Printer-friendly Version

Interactive Discussion 
wavelengths with increasing height. The line shape $V_{k}$ can be calculated as convolution of a Lorentzian profile (pressure broadening) and a Gaussian profile (Doppler broadening) with

$V_{k}(\tilde{v}, z)=\left.L_{k}(\tilde{V}, z) *\right|_{\tilde{v}} G_{k}(\tilde{V}, z)$

$$
=\frac{4 \sqrt{\ln 2}}{\pi^{3 / 2} \cdot b_{\mathrm{WV}, k}(z) \cdot b_{\mathrm{DWV}, k}(z)} \int_{-\infty}^{+\infty} \frac{\exp \left(-4 \ln (2)\left(\frac{\tilde{v}^{\prime}}{b_{\mathrm{DW}, k}(z)}\right)^{2}\right)}{1+4 \cdot\left(\frac{\tilde{v}-\tilde{v}^{\prime}-\tilde{v}_{\mathrm{Wv}, k}+\Delta \tilde{v}_{k}(z)}{b_{\mathrm{W}, k}(z)}\right)^{2}} d \tilde{v}^{\prime} .
$$

with the full width at half maximum (FWHM) of pressure broadening being:

$b_{\mathrm{Wv}, k}(z)=2 \frac{\gamma_{\text {air }, k}\left(p(z)-p_{\mathrm{Wv}}(z)\right)+\gamma_{\mathrm{wv}, k} p_{\mathrm{Wv}}(z)}{p_{0}}\left(\frac{T(z)}{T_{0}}\right)^{0.5}$

where $\gamma_{\text {air, } k}$ and $\gamma_{\mathrm{wv}, k}$ are the coefficients for air broadening and self broadening at standard pressure $p_{0}$, the FWHM of Doppler broadening being:

$b_{\mathrm{DWV}, k}(z)=\frac{2 \tilde{v}_{\mathrm{WV}, k}}{c}\left(\frac{2 \ln (2) R T(z)}{M_{\mathrm{WV}}}\right)^{0.5}$

with the velocity of light $c$, the gas constant $R$, and the molar mass of water vapor $M_{\mathrm{WV}}$, and the pressure shift of the line center being:

$\Delta \tilde{v}_{k}(z)=\Delta \tilde{v}_{0, k} \frac{p(z)}{p_{0}}\left(\frac{T_{0}}{T(z)}\right)^{0.6}$

with $\Delta \tilde{v}_{0, k}$ being the line shift.

15 Finally, the water vapor absorption cross-section is the sum over all absorption lines with their contribution at a certain wave number

$\sigma_{\mathrm{WV}}(\tilde{v}, r)=\sum_{k} \sigma_{k}(\tilde{v}, r)$.

High-resolution atmospheric water vapor measurements with a scanning DIAL

F. Späth et al.

Title Page

Abstract

Introduction

Conclusions

References

Tables

Figures

14

DI

4

Back

Close

Full Screen / Esc

Printer-friendly Version

Interactive Discussion 
Suitable wavelength regions for WV DIAL are found, e.g., near $720 \mathrm{~nm}$ (Bruneau et al., 2001), near $820 \mathrm{~nm}$ (Wulfmeyer and Walther, 2001a, b; Ismail and Browell, 1989; Browell et al., 1989; Ertel et al., 2005; Nehir et al., 2009, 2012; Obland et al., 2010), near 935 nm (Vogelmann et al., 2008; Machol et al., 2004, 2006; Dinovister et al., 2010, 5 Wirth et al., 2009; Fix et al., 2011), and near $1480 \mathrm{~nm}$ (Petrova et al., 2008).

In Fig. 1 the absorption cross-section was plotted for the wave number region from 12210.0 to $12230.0 \mathrm{~cm}^{-1}$ (wavelengths between 819.0 to $817.7 \mathrm{~nm}$ ). This region is used by us because it presents a good compromise between possible Ti:sapphire laser radiation with high power, the tuning range of available seed lasers with high stability 10 and a large range of suitable water-vapor absorption cross sections. The parameters for the calculation, e.g. ground-state energy $E_{\mathrm{B}, k}$, can be accessed from high accuracy laboratory measurements collected in databases, e.g. High-resolution TRANsmission molecular absorption database (HITRAN) described by Rothman et al. $(2009,2013)$. Here the line parameters are taken from the HITRAN compilation 2012 database (Roth15 man et al., 2013). For Fig. 1, we took absorption lines between 12185 and $12255 \mathrm{~cm}^{-1}$ in Eq. (9) into account.

Figure 2 presents the difference of the absorption cross-sections between the two compilations of HITRAN 2008 and HITRAN 2012 (Rothman et al., 2009, 2013) at ground level and for an altitude of $10 \mathrm{~km}$ for the same wave number range as in Fig. 1. 20 The line parameters do partly differ significantly (up to 2 to $4 \%$ ) so that still corresponding uncertainties remain until today. As explained above (Eq. 2), errors in the absorption cross-section - especially at the online wavelength - transfer into measurement errors with the DIAL technique. As we aim at accuracies of better than $5 \%$, care has to be taken in selecting a database as accurate as possible for the absorption cross-section parameters. We believe that HITRAN 2012 fulfills this demand and used this database for analyzing the HOPE data.
ACPD

14, 29057-29099, 2014

High-resolution

atmospheric water vapor measurements with a scanning DIAL

F. Späth et al.

Title Page

Abstract Introduction

Conclusions

References

Tables

Figures

14

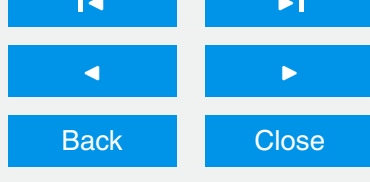

Full Screen / Esc

Printer-friendly Version

Interactive Discussion 


\subsection{Sensitivity analyses}

$\sigma_{\text {eff }}$ is shown in Fig. 3 for several heights between ground level and $10 \mathrm{~km}$ altitude. The atmospheric conditions for the calculation were taken here from the US standard atmosphere (NASA, 1976). With increasing height, the absorption lines become narrower

5 (Eqs. 6 and 7). Additionally, the absorption line peaks are shifted to larger wavelengths with increasing height due to the pressure shift $\Delta \tilde{v}$ in Eq. (8).

It is clear that the US standard atmosphere (NASA, 1976) does not represent the real atmosphere. But it can be used to study the sensitivity of the water vapor DIAL measurements with respect to uncertainties of the absorption cross-section. As discussed by Wulfmeyer and Walther (2001a, b), a relative error in the effective absorption crosssection $\sigma_{\text {eff }}$ is transferred directly to the relative error of the number density of the DIAL measurements according to:

$\frac{\Delta N}{N}=\frac{\Delta \sigma_{\text {eff }}}{\sigma_{\text {eff }}}$

with $N$ being the number density of WV.

The sensitivity of $\sigma_{\text {eff }}$ to temperature, pressure and humidity with height is shown in Fig. 4. The sensitivities to temperature and pressure uncertainties increase with height while those to relative changes in humidity decrease. The profiles are nearly symmetric to zero. The sensitivities to temperature show the opposite sign than to pressure.

To reduce the uncertainties in our data analysis procedure, we modify the standard atmosphere with temperature and pressure values at the DIAL site. If nearby radiosonde measurements are available, we use these if the deviations to the standard atmosphere are significant. Temperature profiles with higher spatial and temporal resolution and closer proximity to the DIAL observations than from radiosoundings, can be obtained from RRL (Behrendt, 2005; Radlach et al., 2008; Hammann et al., 2014). The relative deviations due to humidity uncertainties (Fig. 4c) are small compared to those of temperature and pressure. They decrease with height because of the decreasing amount of humidity. To reduce this uncertainty even further, one can start the water 29065
ACPD

14, 29057-29099, 2014

High-resolution

atmospheric water vapor measurements with a scanning DIAL

F. Späth et al.

Title Page

Abstract

Introduction

Conclusions

References

Tables

Figures

14

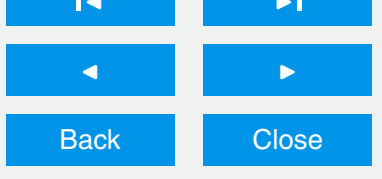

Full Screen / Esc

Printer-friendly Version

Interactive Discussion 
vapor retrieval with the standard-atmosphere humidity profile and iterate with the calculated humidity profile measured by the DIAL.

With, e.g., a pressure uncertainty of $1 \%$ and a temperature uncertainty of $1 \mathrm{~K}$, the total uncertainty of the WV DIAL data analysis procedure is smaller than $1.4 \%$ up 5 to $3 \mathrm{~km}$ and $1.8 \%$ up to $10 \mathrm{~km}$ altitude. This is sufficient for most applications and exceeds the development goals of our DIAL system, which are summarized in Wagner et al. (2013).

\subsection{Wavelength selection}

To improve the performance of the measurements, one can choose transmitter on10 line wavelengths with different absorption cross-section values for different atmospheric conditions, different measurement ranges of interest, and different measurement modes, e.g. for vertical or scanning measurements.

The $\mathrm{UHOH}$ DIAL system is able to operate at wavelengths between 817.7 and $819.0 \mathrm{~nm}$ which is equivalent to wave numbers between 12229.42 and $12210.01 \mathrm{~cm}^{-1}$.

15 The main limitation for this range is set by the injection seeders (Späth et al., 2013). As mentioned above, Fig. 1 shows the WV absorption cross-section spectrum for this range.

With distributed feedback (DFB) laser diodes as injection seeders, we reach a laser frequency stability that allows choosing wavelengths not only at the peak but also on the slope of an absorption line and thus select different values for the absorption crosssection (Späth et al., 2013).

The optimum absorption cross-section $\sigma_{\text {on }}$ depends on the optical thickness $\tau$ of the atmosphere in the maximum measurement range of interest $R . \tau$ is defined by

$\tau=\int_{0}^{R} N_{\mathrm{WV}}(r) \sigma_{\mathrm{on}}(r) \mathrm{d} r$.

\section{ACPD}

14, 29057-29099, 2014

High-resolution

atmospheric water

vapor measurements

with a scanning DIAL

F. Späth et al.

Title Page

Abstract

Introduction

Conclusions

References

Tables

Figures

14

$\rightarrow 1$

4

Back

Close

Full Screen / Esc

Printer-friendly Version

Interactive Discussion 
When assuming that $\sigma_{\text {off }} \ll \sigma_{\text {on }}$. Ramsberger and Gordley (1978) and Ismail and Browell (1989) estimated that an optimum one-way optical thickness of $\tau \approx 1$ minimizes the measurement errors for up to $R$. More accurate simulations revealed an optimum optical thickness in the range cell interval considered for each measurement bin: 5 Wulfmeyer and Walther (2001a, b) demonstrated that present single-shot pulse energies of laser transmitters permit a target differential optical thickness of $\Delta \tau \approx 0.05$. This means that the maximum range $R$ with $\tau \approx 1$ can be separated in about 20 measurement intervals with optimum signal-to-noise ratio.

To estimate $\tau$ for a certain range $R$ in the simulations, we assume a homogenous 10 atmosphere with constant pressure, humidity and temperature, so that $N_{\mathrm{WV}}$ and $\sigma_{\mathrm{on}}$ become range-independent and the optical thickness simplifies to $\tau=N_{\mathrm{wv}} \sigma_{\mathrm{on}} R$. With the condition $\tau=1$ we get then an equation for the absorption cross-section of

$\sigma_{\mathrm{on}}=\frac{1}{N_{\mathrm{Wv}} R}$

For HOPE, we selected the absorption line at a wave number of $12223 \mathrm{~cm}^{-1}$. Figure 5 15 shows a zoom of the absorption cross-section of Fig. 1 into the wave number range of 12220 to $12223.5 \mathrm{~cm}^{-1}$. Differently to Fig. 1 , a temperature of $0^{\circ} \mathrm{C}$, a relative humidity $r h$ of $80 \%$, and an air pressure of $1000 \mathrm{hPa}$ resulting in a water vapor number density of $3 \times 10^{26} \mathrm{~m}^{-3}$ (absolute humidity of $8.95 \mathrm{~g} \mathrm{~m}^{-3}$ ) were used for the calculation. On the slope of the line, different absorption cross-sections $\sigma_{\text {on }}$ can be selected (marked in 20 Fig. 5). For offline, a minimum of the absorption cross-section spectrum at a wave number of $12220.99 \mathrm{~cm}^{-1}$ is chosen.

In Table 1, the 6 example absorption cross-sections marked in Fig. 5 are listed together with the range $R$ at which an optical thickness $\tau$ of 1 is reached (Eq. 12). As one can see, we can select absorption cross sections which cover about one order of magnitude in values and thus optimum ranges between 1 and $10 \mathrm{~km}$ in our example atmosphere. Clearly, this helps in optimizing the sensitivity of the DIAL for different atmospheric conditions and ranges of interest.
ACPD

14, 29057-29099, 2014

High-resolution

atmospheric water vapor measurements with a scanning DIAL

F. Späth et al.

Title Page

Abstract

Introduction

Conclusions

References

Tables

Figures

14

$\rightarrow 1$

4

Back

Close

Printer-friendly Version

Interactive Discussion 


\section{Setup}

In Fig. 6 the UHOH DIAL with its components is depicted. The system can be divided in three parts: (1) the high-power laser transmitter, (2) the transceiver unit, and (3) the receiver with the data acquisition system.

The laser transmitter of the UHOH DIAL is based on an unidirectional Ti:sapphire ring laser (Schiller, 2008; Wagner et al., 2011, 2013) which is end-pumped with the frequency-doubled radiation of a pulsed diode-pumped Nd:YAG laser (Ostermeyer et al., 2005). Frequency-control is realized with the injection seeding technique (Wulfmeyer, 1995; Wulfmeyer et al., 1995, 1996, 1998; Barnes and Barnes, 1993; 10 Barnes et al., 1993; Späth et al., 2013). For the measurements described in this paper, the previous transmitter configuration (Wagner et al., 2013) had been modified in the following aspects: The pump laser has undergone a full redesign and consists now of a unidirectional ring oscillator in triangle configuration. The Nd:YAG laser power was set to up to $38 \mathrm{~W}$ at $1064 \mathrm{~nm}$ resulting in up to $20 \mathrm{~W}$ at $532 \mathrm{~nm}$ used for pumping the

15 Ti:sapphire laser. The resonator of the Ti:sapphire laser has also been changed. Now, four resonator mirrors form a dynamically-stable ring resonator in bow-tie configuration (Metzendorf et al., 2012). In the HOPE experiment, a new seed laser system with two frequency-stabilized DFB laser diodes as injection seeders (Späth et al., 2013) was operated for the first time as part of the transmitter. For switching between online and offline wavelengths between single shots, a 2x1 optical fiber switch was used. It meets the requirements concerning time and crosstalk (Späth et al., 2013) and is much easier to align than the electro-optical deflector used before. The deflector was still implemented and served as a backup. The laser transmitter was operated at two output-power levels depending on the transceiver configuration. The specifications of the Ti:sapphire laser for both configurations are listed in Table 2.

The UHOH DIAL has two configurations for transmitting the laser pulses to the atmosphere and receiving the backscattered lidar signals. In configuration 1 (see Fig. 6), the laser is coupled into an optical fiber and sent out to the atmosphere via a $20 \mathrm{~cm}$

High-resolution atmospheric water vapor measurements with a scanning DIAL

F. Späth et al.

Title Page

Abstract

Introduction

Conclusions

References

Tables

Figures

14

DI

4

Back

$\triangleright$

Close

Printer-friendly Version

Interactive Discussion 
transmitting telescope. The laser output power is restricted to $2 \mathrm{~W}$ in this configuration because the fiber accepts only up to this power before being damaged. The power transmitted into the atmosphere is then $1.6 \mathrm{~W}$.

The backscattered photons are collected with an $80 \mathrm{~cm}$ receiving telescope with a fo5 cal length of $10 \mathrm{~m}$. The light path behind this telescope contains five mirrors. These keep the optical axes on the scanner axes (Coudé concept). All mirrors are highly reflective at $820 \mathrm{~nm}$. The following beam reducers and a lens focus the light on the detector. To block the daylight background, an interference filter (LTIF) is used. Its transmission curve has a full width at half maximum (FWHM) of about $1 \mathrm{~nm}$ around our 10 laser wavelengths. For the measurements in autumn 2013 in Stuttgart-Hohenheim, the daylight-blocking interference filter LTIF was exchanged with one with higher transmission than during HOPE: while the transmission at the online wavelength was $50 \%$ in spring 2013, it became $>90 \%$ in autumn 2013. An avalanche photo diode (APD) detects the signals. The transmitting and receiving telescopes are mounted together on 15 a scanner unit which allows for 3-dimensional measurements. The scanner unit can be operated with speeds between 0.1 to $6^{\circ} \mathrm{s}^{-1}$. The control software of the scanner provides predefined modes like range-height indicator $(\mathrm{RHI})$ and plan-position indicator (PPI) scans in a single direction as well as different types of volume scans.

In configuration 2 (see Fig. 6), the Ti:sapphire laser beam is guided with a highreflection flip mirror (HRFM) to a beam steering mirror (BSM), which reflects the laser pulses to the atmosphere in vertical direction. The laser beam diameter is enlarged 5 -fold with a beam expander, which reduces the beam divergence by a factor of 5 to below $0.1 \mathrm{mrad}$. In addition to the large, vertically pointing $80 \mathrm{~cm}$ telescope, a smaller $20 \mathrm{~cm}$ Schmidt-Cassegrain telescope can be used in this configuration for improving the detection of the near-field signals. To block the daylight background, a $30 \mathrm{~nm}$ broad IF (STIF) is implemented in front of the detector which is mounted to this telecope. For the measurements presented here, however, only data from the large telescope were used. As discussed above, the overlap effects cancel (see Eq. 2) when the system is well aligned. The minimum for the range of the remaining overlap effects is found at
ACPD

14, 29057-29099, 2014

High-resolution

atmospheric water vapor measurements with a scanning DIAL

F. Späth et al.

Title Page

Abstract Introduction

Conclusions

References

Tables

Figures

14

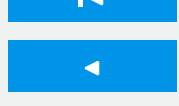

Back

$\Delta \mathbf{I}$

$>$

Close

Full Screen / Esc

Printer-friendly Version

Interactive Discussion 
about $500 \mathrm{~m}$ in our case. In configuration 2, the full output power available from the Ti:sapphire laser of currently $4 \mathrm{~W}$ (Table 2 ) was sent to the atmosphere.

The data acquisition system (DAQ) (14 bit transient recorder Ml.4032, Spectrum $\mathrm{GmbH}$, Germany) records the atmospheric backscatter signals with typically $10 \mathrm{MHz}$ 5 sampling rate resulting in a range resolution of the raw signals $\Delta R$ of $15 \mathrm{~m}$. We record the backscatter signals of each laser shot, which gives us maximum flexibility later when analyzing the data. The DAQ is triggered by the Ti:sapphire laser pulse detected with a photo diode using leakage light behind a high-reflection mirror in the transmitter setup. The online/offline sorting is executed with a hardware signal from the on-

10 line/offline switch of the seeder system. Together with the lidar signals, elevation and azimuth angles of the telescope are stored with each pulse. Within the WV data analysis process, averages in time and range are applied. These are typically $10 \mathrm{~s}$ in time for the online and offline raw data. Afterwards several range bins of data are used for the Savitzky-Golay fit (Savitzky and Golay, 1964) to determine the derivative in Eq. (2).

\section{Measurement examples}

In the following we show vertical measurements taken in autumn 2013 in StuttgartHohenheim (southern Germany, $48^{\circ} 42^{\prime} 40.76^{\prime \prime} \mathrm{N}, 9^{\circ} 12^{\prime} 15.21^{\prime \prime} \mathrm{E}$ ) and some highlights of scanning measurements of the HOPE campaign of spring 2013 near Jülich, Western Germany. These examples illustrate the capabilities of the UHOH DIAL in resolving humidity fields in the height range for which the system was optimized: the atmospheric boundary layer and the lower free troposphere (see Sect. 2.4).

\subsection{Vertical measurements}

For vertical WV measurements we use configuration 2 with maximum laser output power of $4 \mathrm{~W}$. In the following, we present measurements made on 3 October 2013 in Stuttgart-Hohenheim. Within $9 \mathrm{~h}$ from 09:36 to 18:39 UTC, 5 radiosondes were

ACPD

14, 29057-29099, 2014

High-resolution

atmospheric water

vapor measurements

with a scanning DIAL

F. Späth et al.

Title Page

Abstract

Introduction

Conclusions

References

Tables

Figures

14

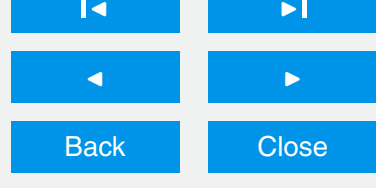

Full Screen / Esc

Printer-friendly Version

Interactive Discussion 
launched at the lidar site (type RS92-SGP of Vaisala). Figure 7 shows the time-height cross-section of the absolute humidity. For the retrieval the online and offline raw signals were averaged over $10 \mathrm{~s}$. For the WV retrieval we calculated the derivation in Eq. (2) with a Savitzky-Golay (SaGo) window length $\Delta R$ of $135 \mathrm{~m}$ (Savitzky and Golay, 5 1964) but keep the vertical step size of $15 \mathrm{~m}$.

For the intercomparisons with the radiosonde data (RS), we averaged the DIAL data over a 20 min period around the radiosonde launch times to reduce the sampling differences. Intercomparisons of WV profiles for the height range from 0.5 up to $4.5 \mathrm{~km}$ for the five cases of 3 October 2013 are shown in Fig. 8.

10 For the noise error analysis, we use the technique of Lenschow et al. (2000), which distinguishes between instrumental and atmospheric noise by extrapolating the autocovariance function to the zero lag (see also Wulfmeyer et al., 2010). Figure 9 shows the instrumental noise error profiles in a height range of 0.5 to $3 \mathrm{~km}$. Also for the noise analysis, $20 \mathrm{~min}$ periods around the radiosonde launching times were used. The noise error profiles mostly compare like expected for the different background conditions in the course of the day (local noon was at $11: 12$ UTC). $\Delta q / q$ is smaller than $0.1 \%$ up to $2500 \mathrm{~m} \mathrm{AGL}$ (above ground level) for all cases; and smaller than $0.5 \%$ up to $3000 \mathrm{~m}$ AGL But interestingly, the noise errors at 14:40 UTC are smaller than at 13:07 and 16:08 UTC. The reason for the lower noise level was a change in the presence of clouds here. On this day, there were mostly clouds present at altitudes of 6 to $8 \mathrm{~km}$ which scattered the sunlight so that the background light was higher than in non-cloudy conditions. These clouds were not present around 14:40 UTC so that the background signal was smaller at that time. Thus we can state, that the noise errors shown in Fig. 9 are mostly larger than those under ideal cloud-free conditions.

25 It is interesting to scale the noise data (Fig. 9) to other resolutions with (Ismail and Browell, 1989)

$$
\frac{\Delta q}{q} \propto(\Delta t)^{-0.5}(\Delta R)^{-1.5}
$$

ACPD

14, 29057-29099, 2014

High-resolution

atmospheric water

vapor measurements

with a scanning DIAL

F. Späth et al.

Title Page

Abstract

Introduction

Conclusions

References

Tables

Figures

14

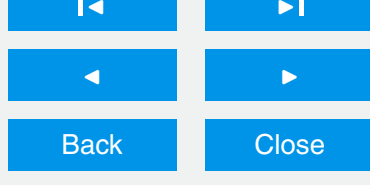

Full Screen / Esc

Printer-friendly Version

Interactive Discussion 
Wulfmeyer and Walther $(2001 a, b)$ showed that this equation still holds in the presence of background noise and speckle errors. We get a relative noise error up to $2500 \mathrm{~m}$ a.g.l. $<1 \%$ for $10 \mathrm{~s}$ time resolution instead of $0.1 \%$ for $20 \mathrm{~min}$ resolution (factor $120^{0.5}$ ). This is very important for turbulence measurements.

We calculated the bias between DIAL and RS data (Behrendt et al., 2007a, b)

$\operatorname{Bias}_{\text {absolute }}\left(z_{1}, z_{2}\right)=\frac{2 \sum_{z=z_{1}}^{z_{2}}\left[q_{\mathrm{DIAL}}(z)-q_{\mathrm{RS}}(z)\right]}{N_{Z}}$

$\operatorname{Bias}_{\text {relative }}\left(z_{1}, z_{2}\right)=\frac{2 \sum_{z=z_{1}}^{z_{2}}\left[q_{\mathrm{DIAL}}(z)-q_{\mathrm{RS}}(z)\right]}{\sum_{z=z_{1}}^{z_{2}}\left[q_{\mathrm{DIAL}}(z)+q_{\mathrm{RS}}(z)\right]}$

with $q_{\mathrm{DIAL}}(z)$ and $q_{\mathrm{RS}}(z)$ being the absolute humidity measured with the DIAL and the RS at height $z$, evaluated in the height interval between $z_{1}$ and $z_{2}$ with $N_{Z}$ data points.

10 The profiles of the absolute and relative bias in $500 \mathrm{~m}$ intervals for all five intercomparisons as well as for their mean profiles were plotted in Fig. 10. The data cover a height range between 0.5 and $3 \mathrm{~km}$, above the noise in the DIAL data becomes too large. The overall bias between the DIAL and the RS is only $(-0.04 \pm 0.11) \mathrm{g} \mathrm{m}^{-3}$ or $(-1.0 \pm 2.3) \%$ which satisfies our development goal (Table 3). From the mean profile 15 we can see an indication for dryer values measured by the DIAL than by the RS in higher altitudes; we plan to investigate this point further in the future by more extensive intercomparisons.

\subsection{Scanning measurements}

To capture the horizontal and vertical WV field in the HOPE domain, scanning measurements with the UHOH DIAL were performed mainly in the directions of the other two

High-resolution atmospheric water vapor measurements with a scanning DIAL

F. Späth et al.

Title Page

Abstract

Introduction

Conclusions

References

Tables

Figures

14

$\rightarrow 1$

Back

Close

Full Screen / Esc

Printer-friendly Version

Interactive Discussion 
supersites. We used the DIAL in configuration 1. The three supersites were oriented in a triangle with distances of about $4 \mathrm{~km}$. Figure 11 shows a sketch of the measurement area and the triangular scan pattern. The first part of the scan was made in RHI mode in the direction of LACROS (Leipzig Aerosol and Cloud Research Observations 5 System). It followed a PPI scan with low elevation from LACROS to JOYCE direction (Jülich ObservatoY for Cloud Evaluation). Then again an $\mathrm{RHI}$ scan back to the vertical was made in direction of JOYCE. Finally, the scanner turned back to the start position staring vertically. Due to the position of the sun, only RHI scans in the direction of JOYCE or LACROS were possible in the afternoon and evening. Depending on the fo10 cus of the IOP, slow scans with scan speeds of 0.1 to $0.3^{\circ} \mathrm{s}^{-1}$ or fast scans with a scan speed of $6^{\circ} \mathrm{s}^{-1}$ were made.

When scanning fast, the DIAL captured also fast changes in the atmosphere: one $\mathrm{RHI}$ scan from vertical to horizon then took only $15 \mathrm{~s}$. The whole triangular pattern of HOPE was consequently performed in only $45 \mathrm{~s}$. Figure 12 shows as example range15 corrected offline backscatter signals of an RHI scan in the direction of JOYCE on 14 April 2013. Three scans in a row were plotted in Fig. 12a for the near-range $(3 \mathrm{~km}$ vertically and $4 \mathrm{~km}$ horizontally). In Fig. $12 \mathrm{~b}$ the data is shown up to $14 \mathrm{~km}$ vertically and $8 \mathrm{~km}$ horizontally. For these plots, no time averaging was applied. The backscatter signals of each offline shot with $125 \mathrm{~Hz}$ are shown. In the near-range plots, one can see fascinating changes in the boundary layer structures between the scans - similar to what has been presented already by use of the volume-imaging lidar (Piironen and Eloranta, 1995) and the Raman-shifted Eye-safe Aerosol Lidar (REAL system) (Mayor and Spuler, 2004). The atmospheric dynamics captured here are mainly due to the presence of gravity waves above the ABL top and breaking Kelvin-Helmholtz waves in the interfacial layer. The interactions of these processes has certainly influence on the water-vapor entrainment flux and will be a key topic of investigations in the future. In the far-range, clouds at an altitude of $5 \mathrm{~km}$ and at altitudes of 10 to $12 \mathrm{~km}$ were detected. For the retrieval of WV averaging over several online and offline laser pulses is usually performed to achieve water vapor data with lower statistical uncertainties. Water vapor
ACPD

14, 29057-29099, 2014

High-resolution

atmospheric water vapor measurements with a scanning DIAL

F. Späth et al.

Title Page

Abstract Introduction

Conclusions

References

Tables

Figures

14

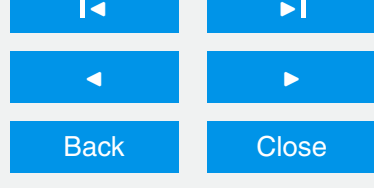

Full Screen / Esc

Printer-friendly Version

Interactive Discussion 
measurements of the UHOH DIAL based on such fast scans are currently analyzed and will be presented later.

In Fig. 13 slower scanning measurements in the directions of LACROS and JOYCE on IOP 5 on 20 April 2013 between 06:03 and 06:27 UTC are presented. The time 5 resolution is $10 \mathrm{~s}$ which results in an angle resolution of $1.5^{\circ}$. One of these $\mathrm{RHI}$ scans took $10 \mathrm{~min}$. The scanning data have been gridded to a horizontal-vertical grid in order to display the atmospheric structures appropriately. Figure $13 a$ and $b$ shows the rangecorrected backscatter signal over a horizontal range of 0.7 to $4.2 \mathrm{~km}$ up to an altitude of $2 \mathrm{~km}$ ( $25 \mathrm{~m}$ grid). Due to the longer path of the laser beam through the aerosol-laden 10 air in lower elevation and the corresponding higher extinction, the signal decrease is stronger in the horizontal than in the vertical direction. The WV data were plotted with a grid resolution of $50 \mathrm{~m}$ in the same range (Fig. 13c and d). Because of higher extinction of the online signal in the moist boundary layer, the noise in a horizontal profile is larger than in a vertical profile. Thus we use for larger distances larger SaGo window 15 lengths $\Delta R$ to reduce the noise and to keep the angle resolution. Up to a distance of $1.3 \mathrm{~km}$ we used $\Delta R=285 \mathrm{~m}$, up to $2.5 \mathrm{~km}$ of $\Delta R=615 \mathrm{~m}$, up to $3.0 \mathrm{~km}$ of $\Delta R=915 \mathrm{~m}$, and up to $4.2 \mathrm{~km}$ of $\Delta R=1995 \mathrm{~m}$. The WV field in the two scanning directions shows several similarities but also significant differences revealing the heterogeneities of the $\mathrm{ABL}$ in the HOPE region. Up to $500 \mathrm{~m}$ altitude, the moist growing $\mathrm{CBL}$ is seen. The residual boundary layer above can be separated indeed in several layers which differ in humidity and in altitude. While the humidity in the CBL and the layer around $1.5 \mathrm{~km}$ is similar for both scan directions, the layer at $1 \mathrm{~km}$ shows larger differences between the scans but also within each scan.

\section{Summary}

25 The DIAL technique was reviewed and the sensitivity of the absorption cross-section concerning temperature, pressure and humidity was investigated. It turned out that uncertainties due to relative changes of temperature and pressure have different sign.
ACPD

14, 29057-29099, 2014

High-resolution

atmospheric water

vapor measurements

with a scanning DIAL

F. Späth et al.

Title Page

Abstract

Introduction

Conclusions

References

Tables

Figures

14

DI

4

Back

Close

Full Screen / Esc

Printer-friendly Version

Interactive Discussion 
The total uncertainty is smaller than $1.4 \%$ up to $3 \mathrm{~km}$ and smaller than $1.8 \%$ up to $10 \mathrm{~km}$ altitude for uncertainties of temperature by $1 \mathrm{~K}$ and of pressure by $1 \%$. The uncertainty due to relative changes of humidity is small and decrease with height.

The UHOH DIAL was operated within HOPE over $180 \mathrm{~h}$ on 18 IOP days to capture 5 the water vapor fields by vertical pointing observations and in slow and fast scanning mode. In this paper we presented the DIAL setup and demonstrated the scanning capability with examples of slow scanning measurements observing the 3-dimensional water-vapor field and fast scanning backscatter measurements showing the aerosol structure in the boundary layer and clouds up to altitudes of $14 \mathrm{~km}$. An intercomparison of the WV profiles with radiosondes showed a very small bias between the instruments of only $(-0.04 \pm 0.11) \mathrm{g} \mathrm{m}^{-3}$ or $(-1.0 \pm 2.3) \%$ for heights between 0.5 and $3.0 \mathrm{~km}$. The noise analysis gave less than $0.1 \%$ instrumental noise for altitudes up to $2.5 \mathrm{~km}$ and less than $0.5 \%$ up to $3 \mathrm{~km}$.

Acknowledgements. The HOPE campaign was funded by the German Research Ministry un15 der the project number 01LK1212A.

\section{References}

Ansmann, A. and Bösenberg, J.: Correction scheme for spectral broadening by Rayleigh scattering in differential absorption lidar measurements of water vapor in the troposphere, Appl. Optics, 26, 3026-3032, 1987.

20 Barnes, J. C., Barnes, N. P., Wang, L. G., and Edwards, W.: Injection seeding II: $\mathrm{Ti}_{2} \mathrm{Al}_{2} \mathrm{O}_{3}$ Experiments, IEEE J. Quantum Elect. 29, 2684-2692, 1993.

Barnes, N. P. and Barnes, J. C.: Injection seeding I: Theory, IEEE J. Quantum Elect., 29, 26702683, 1993.

Behrendt, A.: Temperature measurements with lidar, in: Lidar: Range-Resolved Optical Remote Vol. 102, ISBN: 0-387-40075-3, Springer, New York, 273-305, 2005.

ACPD

14, 29057-29099, 2014

High-resolution

atmospheric water

vapor measurements

with a scanning DIAL

F. Späth et al.

Title Page

Abstract

Introduction

Conclusions

References

Tables

Figures

14

\section{$\Delta$}

4

Back

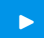

Close

Full Screen / Esc

Printer-friendly Version

Interactive Discussion 
Behrendt, A., Nakamura, T., Onishi, M., Baumgart, R., and Tsuda, T.: Combined Raman lidar for the measurement of atmospheric temperature, water vapor, particle extinction coefficient, and particle backscatter coefficient, Appl. Optics, 41, 36, 7657-7666, 2002.

Behrendt, A., Wulfmeyer, V., Di Girolamo, P., Kiemle, C., Bauer, H. S., Schaberl, T., Summa, D., Whiteman, D. N., Demoz, B. B., Browell, E. V., Ismail, S., Ferrare, R., Kooi, S., Ehret, G., and Wang, J.: Intercomparison of water vapor data measured with lidar during IHOP_2002, Part 1: Airborne to ground-based lidar systems andcomparisons with chilled-mirror hygrometer radiosondes, J. Atmos. Ocean. Tech., 24, 3-21, doi:10.1175/JTECH1924.1, 2007a.

Behrendt, A., Wulfmeyer, V., Kiemle, C., Ehret, G., Flamant, C., Schaberl, T., Bauer, H. S., Kooi, S., Ismail, S., Ferrare, R., Browell, E. V., and Whiteman, D. N.: Intercomparison of water vapor data measured with lidar during IHOP_2002, Part 2: Airborne to airborne systems, J. Atmos. Ocean. Tech., 24, 22-39, doi:10.1175/JTECH1925.1, 2007b.

Behrendt, A., Wulfmeyer, V., Riede, A., Wagner, G., Pal, S., Bauer, H., Radlach, M., and Späth, F.: 3-Dimensional observations of atmospheric humidity with a scanning differential absorption lidar, SPIE Conference Proceeding, 7475, 2009.

Behrendt, A., Pal, S., Aoshima, F., Bender, M., Blyth, A., Corsmeier, U., Cuesta, J., Dick, G., Dorninger, M., Flamant, C., Di Girolamo, P., Gorgar, T., Huang, Y., Kalthoff, N., Khodayar, S., Mannstein, H., Träumner, K., Wieser, A., and Wulfmeyer, V.: Observations of convection initiation processes with a suite of state-of-the-art research instruments during COPS IOP8b, Q.

20 J. Roy. Meteor. Soc., 137, 81-100, 2011.

Behrendt, A., Hammann, E., Späth, F., Riede, A., Metzendorf, S., and Wulfmeyer, V.: Revealing surface layer heterogeneities with scanning Water Vapor DIAL and scanning rotational Raman LIDAR, in: Reviewed and Revised Papers Presented at the 26th International Laser Radar Conference (ILRC 2012), edited by: Papayannis, A., Balis, D., and Amiridis, V., 2529 June 2012, Porto Heli, Greece, paper S7P-17, 913-916, 2012.

Behrendt, A., Blyth, A., Dorninger, M., Kalthoff, N., Flamant, C., Di Girolamo, P., and Richard, E.: Convective prcipitation in complex terrain: results of the COPS campaign, Meteorol. Z. 22, 367-372, doi:10.1127/0941-2948/2013/0541, 2013.

Behrendt, A., Wulfmeyer, V., Hammann, E, Muppa, S. K., and Pal, S.: Profiles of second to thirdorder moments of turbulent temperature fluctuations in the convective boundary layer: First measurements with rotational Raman lidar, Atmos. Chem. Phys. Discuss., 14, 29019-29055, doi:10.5194/acpd-14-29019-2014, 2014.
ACPD

14, 29057-29099, 2014

High-resolution

atmospheric water

vapor measurements

with a scanning DIAL

F. Späth et al.

Title Page

Abstract

Introduction

Conclusions

References

Tables

Figures

14

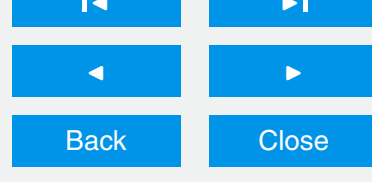

Full Screen / Esc

Printer-friendly Version

Interactive Discussion 
Bengtsson, L., Hodges, K. I., and Hagemann, S.: Sensitivity of the ERA40 reanalysis to the observing system: determination of the global atmospheric circulation from reduced observations, Tellus A, 56, 456-471, doi:10.1111/j.1600-0870.2004.00079.x, 2004.

Bhawar, R., Di Girolamo, P., Summa, D., Flamant, C., Althausen, D., Behrendt, A., Kiemle, C., Bosser, P., Cacciani, M., Champollion, C., Di lorio, T., Engelmann, R., Herold, C., Pal, S., Riede, A., Wirth, M., and Wulfmeyer, V.: The Water vapour intercomparison effort in the framework of the convective and orographically-induced precipitation study: air-borne-toground-based and airborne-to-airborne lidar systems, COPS Special Issue of the Q. J. Roy. Meteor. Soc., 137, 3-30, 325-348, 2011.

10 Browell, E. V., Wilkerson, T. D., and Mcllrath, T. J.: Water vapor differential absorption lidar development and evaluation, Appl. Optics, 18, 3474-3483, 1979.

Browell, E. V., Ismail, S., and Grant, W. B., Differential absorption lidar (DIAL) measurements from air and space, Appl. Phys. B, 67, 399-410, 1998.

Bruneau, D., Quaglia, P., Flamment, C., Meissonnier, M., and Pelon, J.: Airborne iidar LEANDRE II for water-vapor profiling in the troposphere. I. System description, Appl. Optics, 40, 3450-3461, doi:10.1364/AO.40.003450, 2001.

Crook, N. A.: Sensitivity of moist convection forced by boundary layer processes to low-level thermodynamic fields, Mon. Weather Rev., 124, 1767-1785, 1996.

Corsmeier, U., Kalthoff, N., Barthlott, C., Behrendt, A., Di Girolamo, P., Dorninger, M., Aoshima, F., Handwerker, J., Kottmeier, C., Mahlke, H., Mobbs, S., Vaughan, G., Wickert, J., and Wulfmeyer, V.: Driving processes for deep convection over complex terrain: a multi-scale analysis of observations from COPS-IOP 9c, COPS Special Issue of the Q. J. Roy. Meteor. Soc., 137, 137-155, doi:10.1002/qj.754, 2011.

Dierer, S., Arpagaus, M., Seifert, A., Avgoustoglou, E., Dumitrache, R., Grazzini, F., Mercogliano, P., Milelli, M., and Starosta, K.: Deficiencies in quantitative precipitation forecasts: sensitivity studies using the COSMO model, Meteorol. Z., 18, 631-645, doi:10.1127/09412948/2009/0420, 2009.

Dinovitser, A., Hamilton, M. W., and Vincent, R. A.: Stabilized master laser system for differential absorption lidar, Appl. Optics, 49, 3274-3281, doi:10.1364/AO.49.003274, 2010.

30 Ertel, K., Linné, H., and Bösenberg, J., Injection-seeded pulsed Ti:sapphire laser with novel stabilization scheme and capability of dual-wavelength operation, Appl. Optics, 44, 51205126, 2005.

\section{ACPD}

14, 29057-29099, 2014

High-resolution

atmospheric water

vapor measurements

with a scanning DIAL

F. Späth et al.

Title Page

Abstract

Introduction

Conclusions

References

Tables

Figures

14

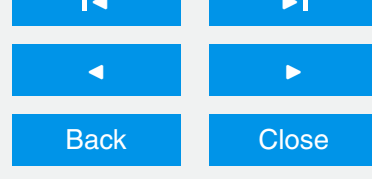

Full Screen / Esc

Printer-friendly Version

Interactive Discussion 
Fix, A., Ehret, G., Löhring, J., Hoffmann, D., and Alpers, M.: Water vapor differential absorption lidar measurements using a diode-pumped all-solid-state laser at $935 \mathrm{~nm}$, Appl. Phys. B, 102, 905, 2011.

Hammann, E., Behrendt, A., Le Mounier, F., and Wulfmeyer, V.: Temperature profiling of the atmospheric boundary layer with rotational raman lidar during the $\mathrm{HD}(\mathrm{CP})^{2}$ observational prototype experiment, Atmos. Chem. Phys. Discuss., 14, 28973-29018, doi:10.5194/acpd14-28973-2014, 2014

Ismail, S. and Browell, E. V.: Airborne and spaceborne lidar measurements of water vapor profiles: a sensitivity analysis, Appl. Optics, 28, 3603-3615, 1989.

10 Kalthoff, N., Fiebig-Wittmaack, M., Meißner, C., Kohler, M., Uriarte, M., Bischoff-Gauß, I., and Gonzales, E.: The energy balance, evapo-transpiration and nocturnal dew deposition of an arid valley in the Andes, J. Arid Environ., 65, 420-443, 2006.

Kalthoff, N., Adler, B., Wieser, A., Kohler, M., Träumner, K., Handwerker, J., Corsmeier, U., Khodayar, S., Lambert, D., Kopmann, A., Kunka, N., Dick, G., Ramatschi, M., Wickert, J., and Kottmeier, C.: KITcube - a mobile observation platform for convection studies deployed during HyMeX, Meteorol. Z., 22, 633-647, 2013.

Kotlarski, S., Keuler, K., Christensen, O. B., Colette, A., Déqué, M., Gobiet, A., Goergen, K., Jacob, D., Lüthi, D., van Meijgaard, E., Nikulin, G., Schär, C., Teichmann, C., Vautard, R., Warrach-Sagi, K., and Wulfmeyer, V.: Regional climate modeling on European scales: a joint standard evaluation of the EURO-CORDEX RCM ensemble, Geosci. Model Dev., 7, 12971333, doi:10.5194/gmd-7-1297-2014, 2014.

Krauss, L., Hauck, C., and Kottmeier, C.: Spatio-temporal soil moisture variability in Southwest Germany observed with a new monitoring network within the COPS domain, Meteorol. Z., 19, 523-537, 2010.

Lenschow, D. H., Wulfmeyer, V., and Senff, C.: Measuring second-through fourth-order moments in noisy data, J. Atmos. Ocean. Tech., 17, 1330-1347, 2000.

Machol, J. L., Ayers, T., Schwenz, K. T., Koenig, K. W., Hardesty, R. M., Senff, C. J., Krainak, M. A., Abshire, J. B., Bravo, H. E., and Sandberg, S. P.: Preliminary measurements with an automated compact differential absorption lidar for the profiling of water vapor, Appl.

$30 \quad$ Optics, 43, 3110-3121, doi:10.1364/AO.43.003110, 2004.

Machol, J. L., Ayers, T., Schwenz, K. T., Koenig, K. W., Hardesty, R. M., Senff, C. J., Krainak, M. A., Abshire, J. B., Bravo, H. E., and Sandberg, S. P.: Preliminary measurements
ACPD

14, 29057-29099, 2014

High-resolution

atmospheric water

vapor measurements

with a scanning DIAL

F. Späth et al.

Title Page

Abstract

Introduction

Conclusions

References

Tables

Figures

14

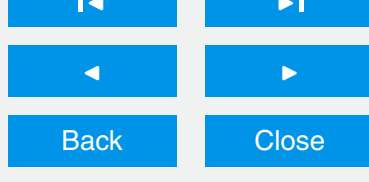

Full Screen / Esc

Printer-friendly Version

Interactive Discussion 
with an automated compact differential absorption lidar for the profiling of water vapor: errata, Appl. Optics, 45, 3544-3544, 2006.

Mayor, S. D. and Spuler, S. M.: Raman-shifted eye-safe aerosol lidar, Appl. Optics, 43, 39153924, 2004.

5 Melfi, S. H., Lawrence, J. D., and McCormick, M. P.: Observation of Raman scattering by water vapor in the atmosphere, Appl. Phys. Lett., 15, 295-297, 1969.

Metzendorf, S., Behrendt, A., Späth, F., and Wulfmeyer, V.: High-power laser transmitter of the UHOH water vapor DIAL, in: Reviewed and Revised Papers Presented at the 26th International Laser Radar Conference (ILRC 2012), edited by: Papayannis, A., Balis, D., and Amiridis, V., 25-29 June 2012, Porto Heli, Greece, paper S1P-11, 117-120, 2012.

Muppa, S. K., Behrendt, A., Späth, F., Wulfmeyer, V., Metzendorf, S., and Riede, A.: Turbulent humidity fluctuations in the convective boundary layer: case studies using DIAL measurements, Atmos. Chem. Phys., in preparation, 2014.

NASA (National Aeronautics and Space Administration): US Standard Atmosphere, 1976.

15 Nehrir, A. R., Repasky, K. S., Carlsten, J. L., Obland, M. D., and Shaw, J. A.: Water vapor profiling using a widely tunable, amplified diode-laser-based differential absorption lidar (DIAL), J. Atmos. Ocean. Tech., 26, 733-745, 2009.

Nehrir, A. R., Repasky, K. S., and Carlsten, J. L.: Micropulse water vapor differential absorption lidar: transmitter design performance, Opt. Express, 20, 25137-25151, 2012.

Obland, M. D., Repasky, K. S., Nehrir, A. R., Carlsten, J. L., and Shaw, J. A., Development of a widely tunable amplified diode laser differential absorption lidar for profiling atmospheric water vapor, J. Appl. Remote Sens., 4, 043515, 2010.

Ostermeyer, M., Kappe, P., Menzel, R., and Wulfmeyer, V.: Diode-pumped Nd:YAG master oscillator power amplifier with high pulse energy, excellent beam quality, and frequency-stabilized master oscillator as a basic for a next-generation lidar system, Appl. Optics, 44, 582-590, 2005.

Petrova-Mayor, A., Wulfmeyer, V., and Weibring, P.: Development of an eye-safe solid-state tunable laser transmitter in the 1.4-1.5- $\mu \mathrm{m}$ wavelength region based on $\mathrm{Cr}^{4+}$ :YAG crystal for lidar applications, Appl. Optics, 47, 1522-1534, 2008.

so Piironen, A. K. and Eloranta, E. W.: Convective boundary layer mean depths, cloud base altitudes, cloud top altitudes, cloud coverages, and cloud shadows obtained from Volume Imaging Lidar data, J. Geophys. Res., 100, 25569-25576, 1995.

\section{ACPD}

14, 29057-29099, 2014

High-resolution

atmospheric water

vapor measurements

with a scanning DIAL

F. Späth et al.

Title Page

Abstract

Introduction

Conclusions

References

Tables

Figures

14

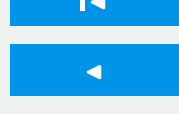

Back

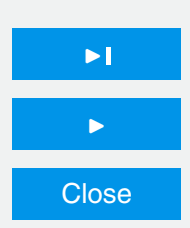

Full Screen / Esc

Printer-friendly Version

Interactive Discussion 
Radlach, M., Behrendt, A., and Wulfmeyer, V.: Scanning rotational Raman lidar at $355 \mathrm{~nm}$ for the measurement of tropospheric temperature fields, Atmos. Chem. Phys., 8, 159-169, doi:10.5194/acp-8-159-2008, 2008.

Remsberg, E. E. and Gordley, L. L.: Analysis of differential absorption lidar from the Space Shuttle, Appl. Optics, 17, 624-630, 1978.

Rothman, L. S., Gordon, I. E., Barbe, A., Chris Benner, D., Bernath, P. F., Birk, M., Boudon, V., Brown, L. R., Campargue, A., Champion, J.-P., Chance, K., Coudert, L. H., Dana, V., Devi, V. M., Fally, S., Flaud, J.-M., Ramache, R. R., Goldman, A., Jacquemart, D., Kleiner, I., Lacome, N., Lafferty, W. J., Mandin, J.-Y., Massie, S. T., Mikhailenko, S. N., Miller, C. E., Moazzen-Ahmadi, N., Naumenko, O. V., Nikitin, A. V., Orphal, J., Perevalov, V. I., Perrin, A., Predoi-Cross, A., Rinsland, C. P. Rotger, M., Simeckova, M., Smith, M. A. H., Sung, K., Tashkun, S. A., Tennyson, J., Toth, R. A., Vandaele, A. C., and Vander Auwera, J.: The HITRAN 2008 molecular spectroscopic database, J. Quant. Spectrosc. Ra., 110, 533-572, 2009.

Rothman, L. S., Gordon, I. E., Babikov, Y., Barbe, A., Chris Benner, D., Bernath, P. F., Birk, M., Bizzocchi, L., Boudon, V., Brown, L. R., Campargue, A., Chance, K., Cohen, E. A., Coudert, L. H., Devi, V. M., Drouin, B. J., Fayt, A., Flaud, J.-M., Gamache, R. R., Harrison, J. J., Hartmann, J.-M., Hill, C., Hodges, J. T., Jacquemart, D., Jolly, A., Lamouroux, J., Le Roy, R. J., Li, G., Long, D. A., Lyulin, O. M., Mackie, C. J., Massie, S. T., Mikhailenko, S., Müller, H. S. P., Naumenko, O. V., Nikitin, A. V., Orphal, J., Perevalov, V., Perrin, A., Polovtseva, E. R., Richard, C., Smith, M. A. H., Starikova, E., Sung, K., Tashkun, S., Tennyson, J., Toon, G. C., Tyuterev VI., G., and Wagner, G. W.: The HITRAN 2012 Molecular Spectroscopic Database, J. Quant. Spectrosc. Ra, 130, 4-50, 2013.

Savitzky, A. and Golay, M. J. E.: Smoothing and differentiation of data by simplyfied least squares procedures, Anal. Chem., 36, 1627-1639, doi:10.1021/ac60214a047, 1964.

Schotland, R. M.: Some observations of the vertical profile of water vapor by means of a ground based optical radar, in: Proceedings of the Fourth Symposium on Remote Sensing of Environment, 12-24 April 1966, U. Michigan, Ann Arbor, 1966.

Schotland, R. M.: Errors in the lidar measurement of atmospheric gases by differential absorption, J. Appl. Meteorol., 13, 71-77, 1974.

Schiller, M.: A high-power laser transmitter for ground-based and airborne water-vapor measurements in the troposphere, Doctoral Thesis, University of Hohenheim, 2009.
ACPD

14, 29057-29099, 2014

High-resolution

atmospheric water

vapor measurements

with a scanning DIAL

F. Späth et al.

Title Page

Abstract

Introduction

Conclusions

References

Tables

Figures

14

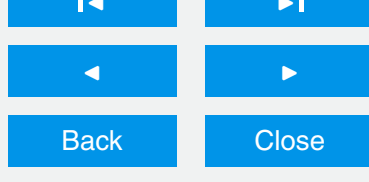

Full Screen / Esc

Printer-friendly Version

Interactive Discussion 
Späth, F., Metzendorf, S., Behrendt, A., Wizemann, H. D., Wagner, G., and Wulfmeyer, V.: Online/offline injection seeding system with high frequency-stability and low crosstalk for water vapor DIAL, Opt. Commun., 309, 37-43, doi:10.1016/j.optcom.2013.07.003, 2013.

Stevens, B. and Bony, S.: What are climate models missing?, Science, 340, 1053, doi:10.1126/science.1237554, 2013.

Träumner, K: Einmischprozesse am Oberrand der konvektiven atmosphärischen Grenzschicht, Doctoral Thesis, Karlsruhe Institute of Technology, 2010 (in German).

Vogelmann, H. and Trickl, T.: Wide range sounding of free tropospheric water vapor with a differential absorption lidar (DIAL) at a high altitude station, Appl. Optics, 47, 2116-2132,

10 doi:10.1364/AO.47.002116, 2008.

Wagner, G., Wulfmeyer, V., and Behrendt, A.: Detailed performance modeling of a pulsed highpower single-frequency Ti:sapphire laser, Appl. Optics, 50, 5921-5937, 2011.

Wagner, G., Behrendt, A., Wulfmeyer, V., Späth, F., and Schiller, M.: High-power Ti:sapphire laser at $820 \mathrm{~nm}$ for scanning ground-based water-vapor differential absorption lidar, Appl.

15 Optics, 52, 2454-2469, 2013.

Warrach-Sagi, K., Schwitalla, T., Wulfmeyer, V., and Bauer, H.-S.: Evaluation of a climate simulation based on the WRF-NOAH model system: precipitation in Germany, Clim. Dynam., 41, 755-774, doi:10.1007/s00382-013-1727-7, 2013.

Whiteman, D. N., Melfi, S. H., and Ferrare, R. A.: Raman lidar system for the measurement of water vapor and aerosols in the Earth's atmosphere, Appl. Optics, 31, 3068-3082, 1992.

Wirth, M., Fix, A., Mahnke, P., Schwarzer, H., Schrandt, F., and Ehret, G.: The airborne multiwavelength water vapor differential absorption lidar WALES: system design and performance, Appl. Phys. B, 96, 201, 2009.

Wulfmeyer, V.: DIAL-Messungen von vertikalen Wasserdampfverteilungen - ein Lasersystem für Wasserdampf- und Temperaturmessungen in der Troposphäre, Max-Planck-Institute of Meteorology, Examensarbeit No. 34, ISSN 0938-5177, Doctoral Thesis, Hamburg, 1995 (in German).

Wulfmeyer, V. and Bösenberg J.: Single-mode operation of an injection-seeded alexandrite ring laser for application in water-vapor and temperature differential absorption lidar, Opt. Lett., 30 21, 1150-1152, 1996.

Wulfmeyer, V. and Bösenberg, J.: Ground-based differential absorption lidar for water-vapor and temperature profiling: requirements, development, and specifications of a high-performance laser transmitter, Appl. Optics, 37, 3804-3824, 1998.
ACPD

14, 29057-29099, 2014

High-resolution

atmospheric water

vapor measurements

with a scanning DIAL

F. Späth et al.

Title Page

Abstract

Introduction

Conclusions

References

Tables

Figures

14

4

Back

$\triangleright$

Close

Full Screen / Esc

Printer-friendly Version

Interactive Discussion 
Wulfmeyer, V. and Walther, C.: Future performance of ground-based and airborne water-vapor differential absorption lidar. I: Overview and Theory, Appl. Optics, 40, 5304-5320, 2001a.

Wulfmeyer, V. and Walther, C.: Future performance of ground-based and airborne water-vapor differential absorption lidar. II: Simulations of the precision of a near-infrared, high power system, Appl. Optics, 40, 5321-5336, 2001b.

Wulfmeyer, V., Bösenberg, J., Lehmann, S., Senff, C., and Schmitz, St.: Injection-seeded alexandrite ring laser: performance and application in a water-vapor differential absorption lidar, Opt. Lett., 20, 638-640, 1995.

Wulfmeyer, V., Behrendt, A., Bauer, H.-S., Kottmeier, C., Corsmeier, U., Blyth, A., Craig, G., Schumann, U., Hagen, M., Crewell, S., Di Girolamo, P., Flamant, C., Miller, M., Montani, A., Mobbs, S., Richard, E., Rotach, M. W., Arpagaus, M., Russchenberg, H., Schlüssel, P., König, M., Gärtner, V., Steinacker, R., Dorninger, M., Turner, D. D., Weckwerth, T., Hense, A., and Simmer, C.: The convective and orographically-induced precipitation study: a research and development project of the world weather research program for improving quantitative precipitation forecasting in low-mountain regions, B. Am. Meteorol. Soc., 89 1477-1486, doi:10.1175/2008BAMS2367.1, 2008.

Wulfmeyer, V., Turner, D. D., Pal, S., and Wagner, E.: Can water vapour raman lidar resolve profiles of turbulent variables in the convective boundary layer?, Bound.-Lay. Meteorol., doi:10.1007/s10546-010-9494-z, 2010.

20 Wulfmeyer, V., Behrendt, A., Kottmeier, C., Corsmeier, U., Barthlott, C., Craig, G. C., Hagen, M., Althausen, D., Aoshima, F., Arpagaus, M., Bauer, H.-S., Bennett, L., Blyth, A., Brandau, C., Champollion, C., Crewell, S., Dick, G., Di Girolamo, P., Dorninger, M., Dufournet, Y., Eigenmann, R., Engelmann, R., Flamant, C., Foken, T., Gorgas, T., Grzeschik, M., Handwerker, J., Hauck, C., Höller, H., Junkermann, W., Kalthoff, N., Kiemle, C., Klink, S., König, M., Krauss, L., Long, C. N., Madonna, F., Mobbs, S., Neininger, B., Pal, S., Peters, G., Pigeon, G., Richard, E., Rotach, M. W., Russchenberg, H., Schwitalla, T., Smith, V., Steinacker, R., Trentmann, J., Turner, D. D., van Baelen, J., Vogt, S., Volkert, H., Weckwerth, T., Wernli, H., Wieser, A., and Wirth, M.: The convective and orographically induced precipitation study (COPS): the scientific strategy, the field phase, and first highlights, COPS Special Issue of the Q. J. Roy. Meteor. Soc., 137, 3-30, doi:10.1002/qj.752, 2011.

Wulfmeyer, V., Behrendt, A., Bauer, H.-S., Schwitalla, T., and Warrach-Sagi, K.: Observations and simulations of soil-vegetation-atmosphere feedback with a new lidar sensor synergy and

\section{ACPD}

14, 29057-29099, 2014

High-resolution

atmospheric water

vapor measurements

with a scanning DIAL

F. Späth et al.

Title Page

Abstract

Introduction

Conclusions

References

Tables

Figures

14

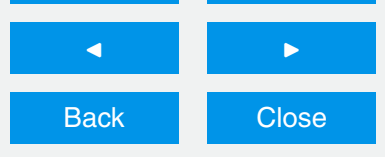

Full Screen / Esc

Printer-friendly Version

Interactive Discussion 
the WRF-NOAH-MP model in the grey zone, 7th International Scientific Conference on the Global Water and Energy Cycle, 14-17 July, Den Haag, the Netherlands, 2014a.

Wulfmeyer, V., Warrach-Sagi, K., Schwitalla, T., Bauer, H.-S., and Milovac, J.: Towards seamless mesoscale prediction of the land system for Europe, The World Weather Open Science

Conference, 16-21 August 2014, Montreal, Canada, 2014b.

\section{ACPD}

\section{4, 29057-29099, 2014}

High-resolution

atmospheric water

vapor measurements

with a scanning DIAL

F. Späth et al.

Title Page

Abstract

Introduction

Conclusions

References

Tables

Figures

14

।

4

Back

$\triangleright$

Full Screen / Esc

Printer-friendly Version

Interactive Discussion 
Table 1. Online absorption cross-section $\sigma_{\mathrm{wV}}$ for six different desired measurement ranges $R$ for which an optical thickness $\tau=1$ is reached and one for offline with corresponding wave numbers and wavelengths are listed for an absolute humidity of $q=8.95 \mathrm{~g} \mathrm{~m}^{-3}$.

\begin{tabular}{lcccc}
\hline $\begin{array}{l}\text { Wave number } \\
\text { in } \mathrm{cm}^{-1}\end{array}$ & $\begin{array}{c}\text { Wavelength } \\
\text { in } \mathrm{nm}\end{array}$ & $\begin{array}{c}\text { Absorption Cross-section } \sigma_{\mathrm{Wv}} \\
\text { in } 10^{-27} \mathrm{~m}^{2}\end{array}$ & $\begin{array}{c}N \cdot R \\
\text { in } 10^{29} \mathrm{~m}^{-2}\end{array}$ & $\begin{array}{c}\text { Range } R \\
\text { in } \mathrm{km}\end{array}$ \\
\hline 12222.90 & 818.1364 & 3.342 & 3.0 & 1.0 \\
12222.82 & 818.1418 & 1.578 & 6.3 & 2.1 \\
12222.76 & 818.1458 & 1.008 & 9.9 & 3.3 \\
12222.72 & 818.1485 & 0.810 & 12.3 & 4.1 \\
12222.68 & 818.1512 & 0.625 & 16.1 & 5.4 \\
12222.53 & 818.1612 & 0.322 & 31.0 & 10.4 \\
12220.99 & 818.2643 & 0.049 & 204.1 & 68.0 (Offline) \\
\hline
\end{tabular}

\section{ACPD}

14, 29057-29099, 2014

High-resolution atmospheric water vapor measurements with a scanning DIAL

F. Späth et al.

\section{Title Page}

Abstract

Introduction

Conclusions

References

Tables

Figures

14

4

Back

$>$

\section{Close}

Full Screen / Esc

Printer-friendly Version

Interactive Discussion 
Table 2. Transmitter specifications during HOPE for two transceiver configurations.

\begin{tabular}{|c|c|c|}
\hline Parameter & Fiber configuration & Mirror configuration \\
\hline Averaged pump power & $14 \mathrm{~W}$ & $20 W$ \\
\hline Repetition rate & \multicolumn{2}{|c|}{$250 \mathrm{~Hz}$} \\
\hline Averaged Ti:sapphire output power & $2 W$ & $4 W$ \\
\hline Pulse energy & $8 \mathrm{~mJ}$ & $16 \mathrm{~mJ}$ \\
\hline Pulse duration & \multicolumn{2}{|c|}{$60 \mathrm{~ns}$} \\
\hline Frequency switching & \multicolumn{2}{|c|}{$\begin{array}{l}\text { Shot-to-shot on-/offline } \\
2 \times 1 \text { optical fiber switch }\end{array}$} \\
\hline Wavelength range & \multicolumn{2}{|c|}{$817.7-819.0 \mathrm{~nm}$} \\
\hline $\begin{array}{l}\text { Averaged output power sent } \\
\text { into the atmosphere }\end{array}$ & $1.6 \mathrm{~W}$ & $4 \mathrm{~W}$ \\
\hline
\end{tabular}

14, 29057-29099, 2014

High-resolution atmospheric water vapor measurements with a scanning DIAL

F. Späth et al.

Title Page

Abstract

Introduction

Conclusions

References

Tables

Figures

14

4

Back

Close

Printer-friendly Version

Interactive Discussion 
Table 3. Intercomparisons between WV DIAL and radiosonde profiles for the measurements on 3 October 2013 in Stuttgart-Hohenheim with respect to absolute and relative bias for the height range of 0.5 to $3 \mathrm{~km}$.

\begin{tabular}{lrr}
\hline Time & BIAS & BIAS \\
UTC & {$\left[\mathrm{g} \mathrm{m}^{-3}\right]$} & {$[\%]$} \\
\hline $09: 52$ & -0.019 & -0.298 \\
$11: 26$ & 0.053 & 0.650 \\
$13: 07$ & 0.068 & 1.360 \\
$14: 40$ & -0.074 & -2.177 \\
$16: 08$ & -0.210 & -4.419 \\
\hline Overall & $-0.04 \pm 0.11$ & $-1.0 \pm 2.3$ \\
\hline
\end{tabular}

\section{ACPD}

14, 29057-29099, 2014

High-resolution atmospheric water vapor measurements with a scanning DIAL

F. Späth et al.

Title Page

Abstract

Introduction

Conclusions

References

Tables

Figures

14

Back

Full Screen / Esc

Printer-friendly Version

Interactive Discussion 


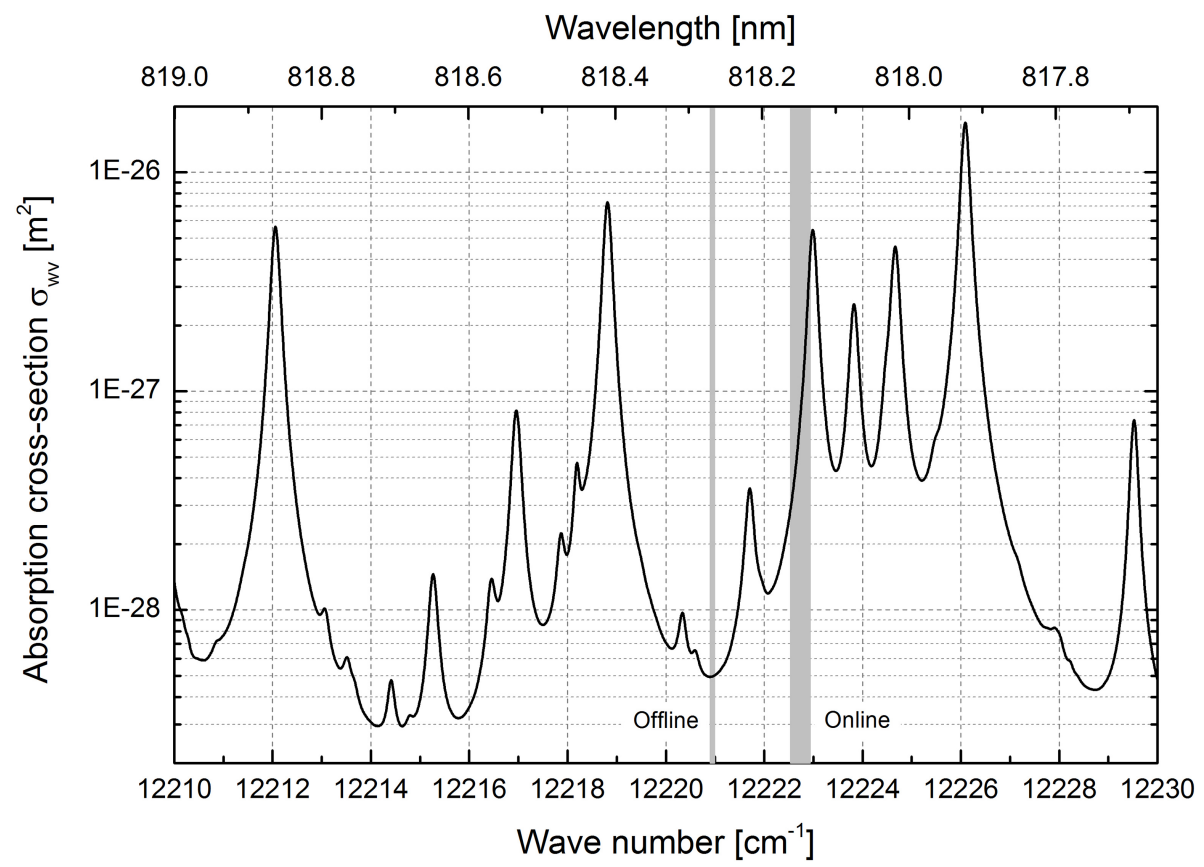

Figure 1. Water vapor absorption cross-sections for $T=15^{\circ} \mathrm{C}, p=1013.25 \mathrm{hPa}$ and $N_{\mathrm{wV}}=$ $1.7 \times 10^{23} \mathrm{~m}^{-3}$ (ground level of NASA 1976 standard atmosphere) was plotted in the tuning range of the DFB seed lasers. The grey bars indicate the online and offline wave number regions used throughout this work.

\section{ACPD}

14, 29057-29099, 2014

High-resolution atmospheric water vapor measurements with a scanning DIAL

F. Späth et al.

\section{Title Page}

14 $>1$

\section{4}

\section{Full Screen / Esc}

Printer-friendly Version

Interactive Discussion 


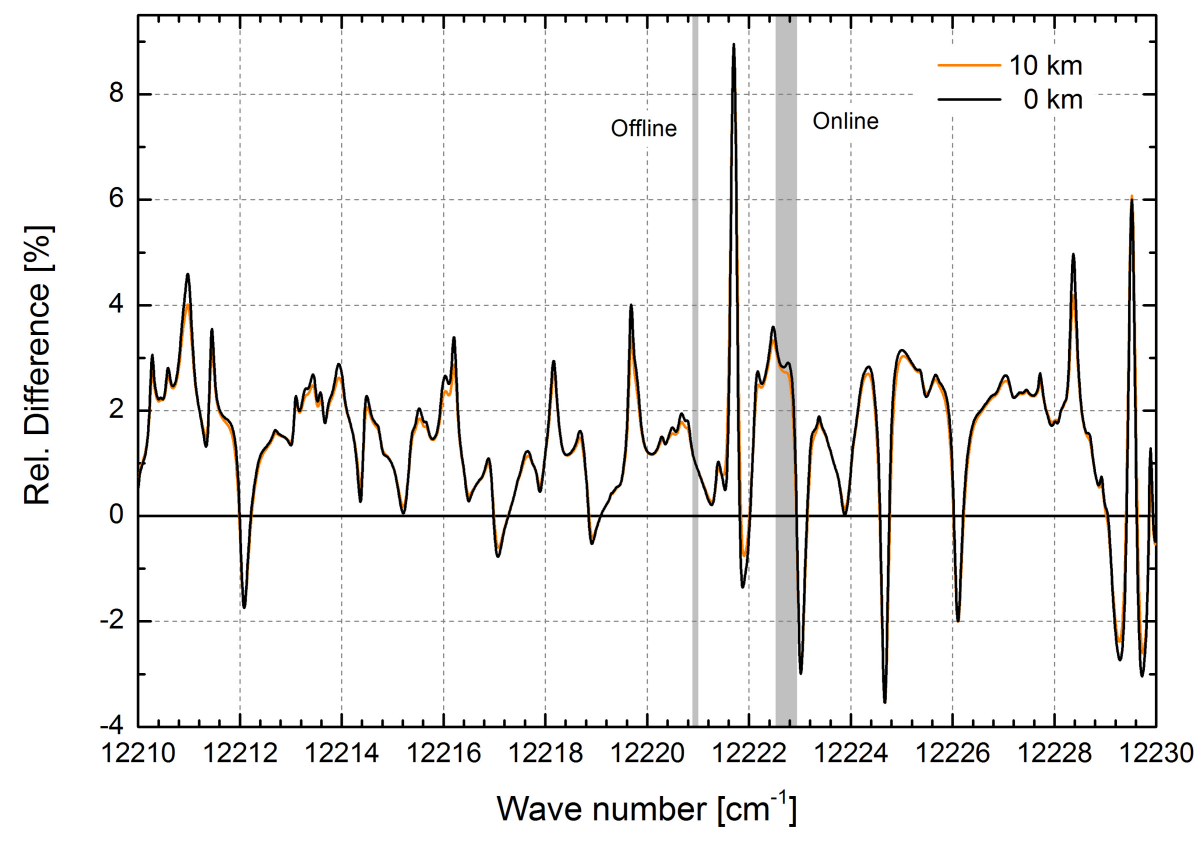

Figure 2. The relative difference of the absorption cross-sections calculated with HITRAN 2008 and HITRAN 2012 at heights of $0 \mathrm{~km}$ and $10 \mathrm{~km}$ above ground was plotted for a standard atmosphere (NASA, 1976). The grey bars indicate the online and offline wave numbers used.

\section{ACPD}

14, 29057-29099, 2014

High-resolution atmospheric water vapor measurements with a scanning DIAL

F. Späth et al.

Title Page

14 $\Delta$

4

Back

Close

Printer-friendly Version

Interactive Discussion 


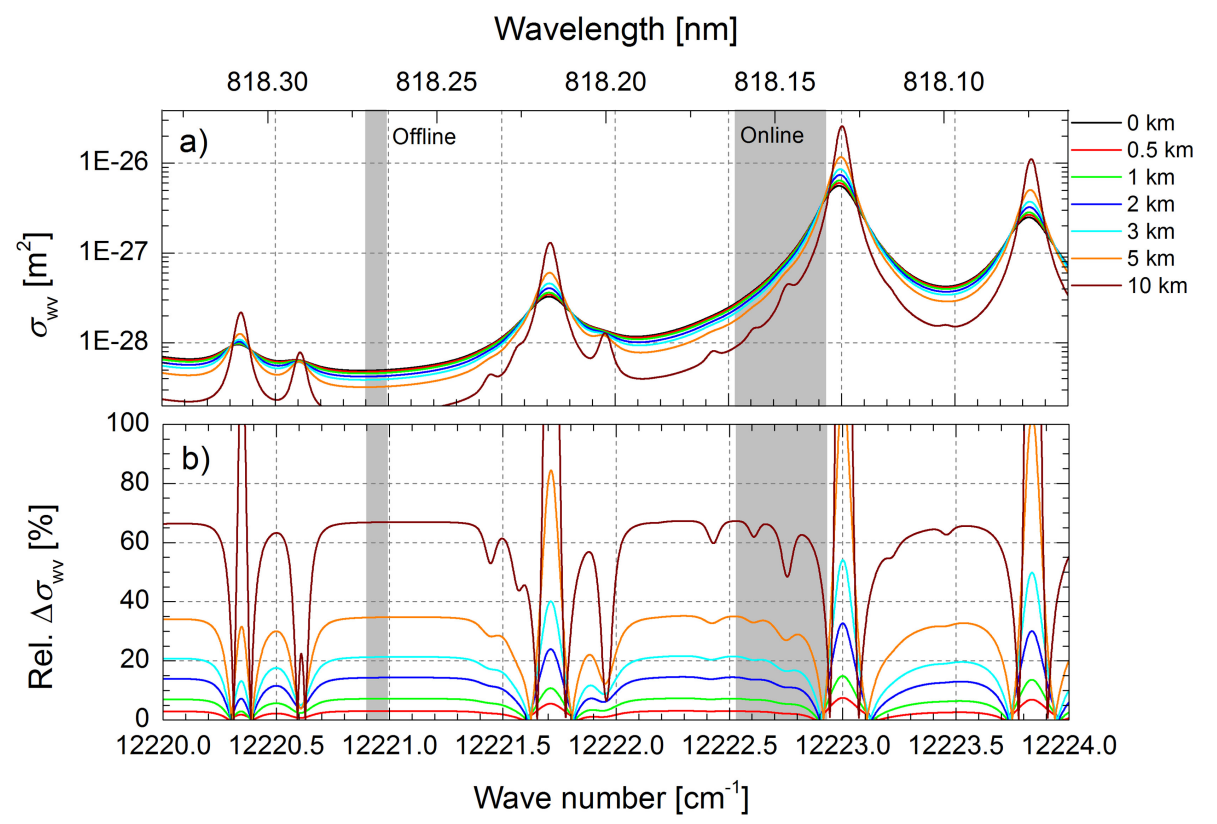

Figure 3. (a) Water vapor absorption cross-sections $\sigma_{W v}$ at different heights and (b) the deviation relative to the ground values in the wave number range of 12220 and $12224 \mathrm{~cm}^{-1}$ are shown. The atmospheric parameters for the different heights are taken from the standard atmosphere (NASA, 1976). The grey bars indicate the online and offline wave numbers used throughout this work.

\section{ACPD}

\section{4, 29057-29099, 2014}

\section{High-resolution} atmospheric water vapor measurements with a scanning DIAL

\section{F. Späth et al.}

Title Page

Abstract

Introduction

Conclusions

References

Tables

Figures

14

DI

4

Back

Close

Printer-friendly Version

Interactive Discussion 


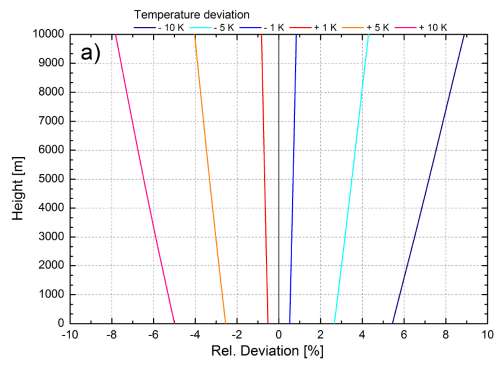

\section{ACPD}

14, 29057-29099, 2014
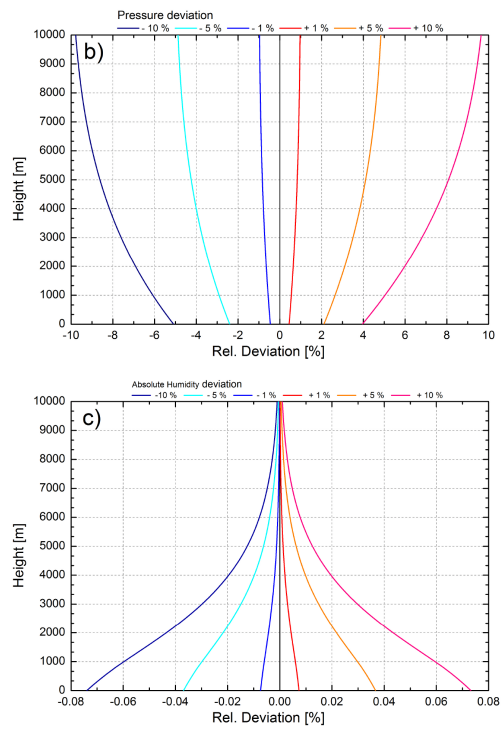

High-resolution atmospheric water vapor measurements with a scanning DIAL

F. Späth et al.

Title Page

Abstract

Introduction

Conclusions

References

Tables

Figures

14

4

Back

Full Screen / Esc

Printer-friendly Version

Interactive Discussion ture $T$ by $\pm 1, \pm 5$, and $\pm 10 \mathrm{~K}$, (b) the pressure and (c) absolute humidity by $\pm 1, \pm 5$, and $\pm 10 \%$, respectively. The main deviation comes from the temperature dependency but with different sign than of the pressure and humidity dependency. 


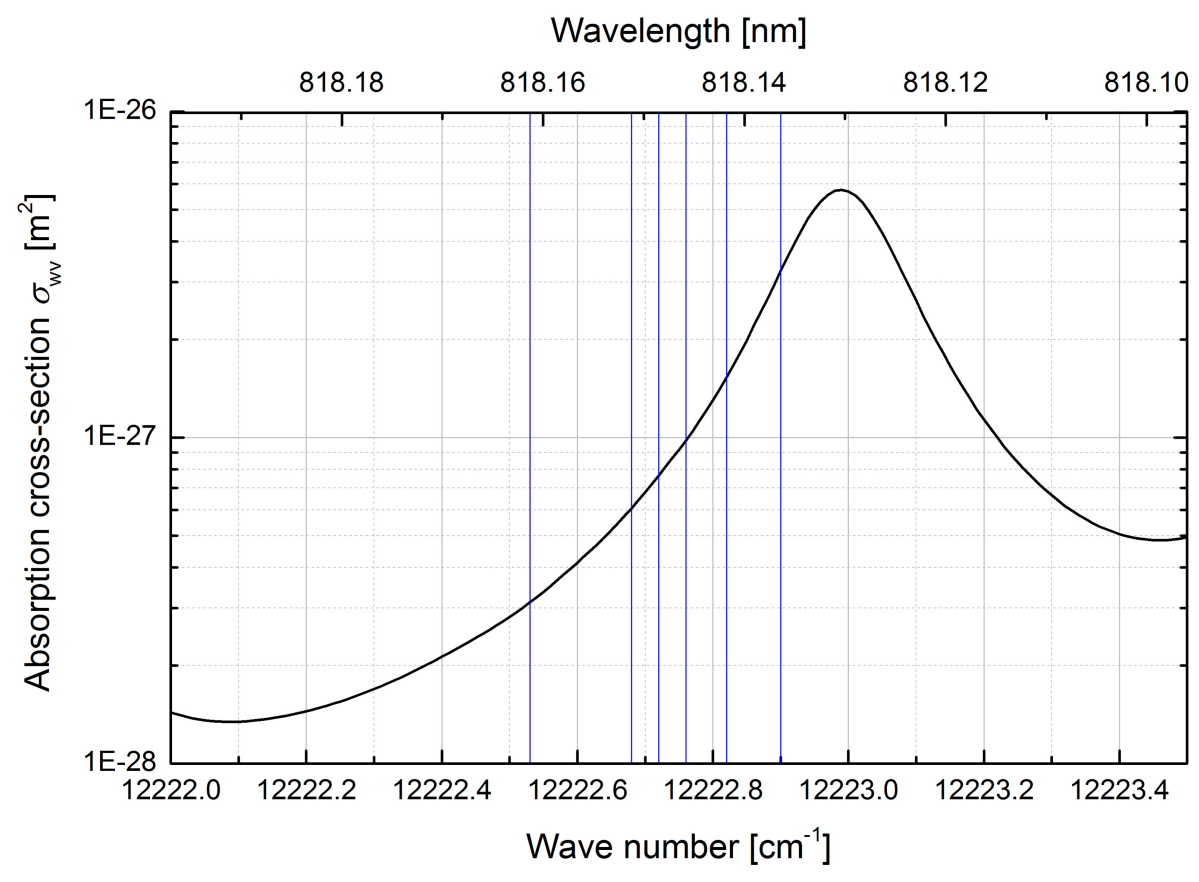

Figure 5. The water vapor absorption cross-section spectrum is shown in the wave number range between 12222.0 and $12223.5 \mathrm{~cm}^{-1}$. The spectrum was calculated for an atmospheric condition of $T=0^{\circ} \mathrm{C}, p=1000 \mathrm{hPa}$ and $r h=80 \%$ which we expected for HOPE. The blue lines indicate the wave numbers for the calculated online wave numbers which are also listed in Table 1.

\section{ACPD}

14, 29057-29099, 2014

High-resolution atmospheric water vapor measurements with a scanning DIAL

F. Späth et al.

Title Page

Abstract

Introduction

Conclusions

References

Tables

Figures

14

DI

Back

Close

Printer-friendly Version

Interactive Discussion 


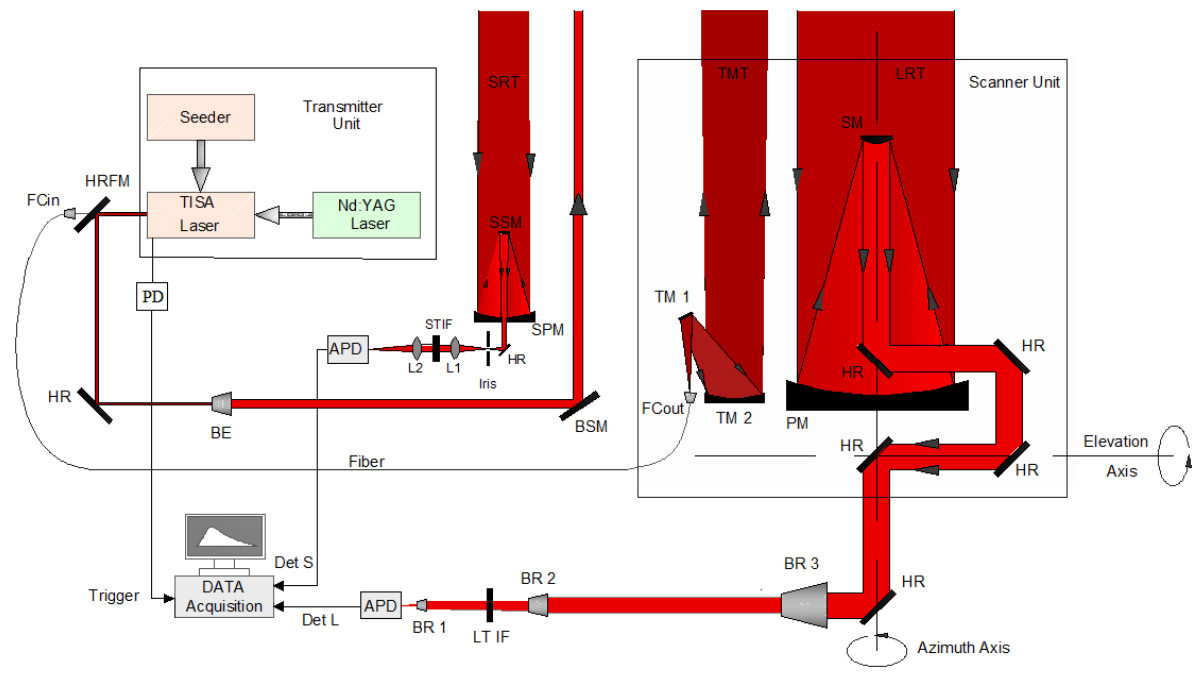

Figure 6. Setup of the UHOH DIAL is depicted with the transmitter unit, beam steering mirror (BSM) and small fiber-coupled transmitting telescope (TMT), large and small receiving telescopes (SRT/LRT), and the data acquisition. FCin/FCout - fiber coupler input/output, HRFM high-reflection coated flip mirror, HR - high-reflection coated mirror, PD - photo diode, SSM - small telescope secondary mirror, SPM - small telescope primary mirror, L1/L2 - lens 1/2, STIF - small telescope interference filter, APD - avalanche photo diode, BE - beam expander, TM1/TM2 - transmitting telescope mirror 1/2, PM - large telescope primary mirror, SM - large telescope secondary mirror, LTIF - large telescope interference filter, BR1 to BR 3 - beam reducer, Det $\mathrm{S} / \mathrm{L}$ - detector signal small/large telescope.

\section{ACPD}

14, 29057-29099, 2014

High-resolution atmospheric water vapor measurements with a scanning DIAL

F. Späth et al.

Title Page

Abstract

Introduction

Conclusions

References

Tables

Figures

14

DI

4

Back

Close

\section{Full Screen / Esc}

Printer-friendly Version

Interactive Discussion 


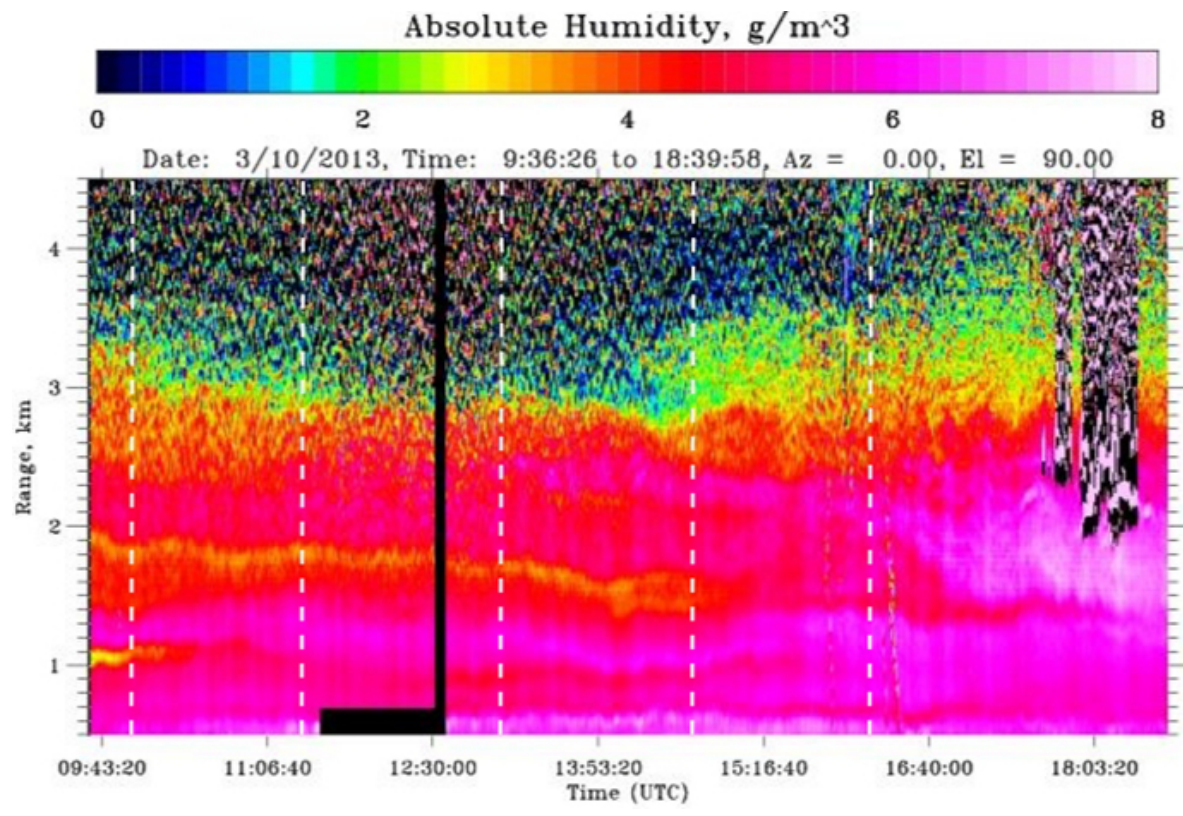

\section{High-resolution atmospheric water} vapor measurements with a scanning DIAL

F. Späth et al.

Figure 7. Vertical measurements of 3 October 2013 from 09:36-18:39 UTC is shown with a temporal resolution of $\Delta t$ of $10 \mathrm{~s}$ and a SaGo window length $\Delta R$ of $135 \mathrm{~m}$. The measurements were taken in Stuttgart-Hohenheim. Dashed lines indicate the radiosonde launch times.

Title Page

Abstract

Introduction

Conclusions

References

Tables

Figures

14

$<$

Back

Close

Full Screen / Esc

Printer-friendly Version

Interactive Discussion 


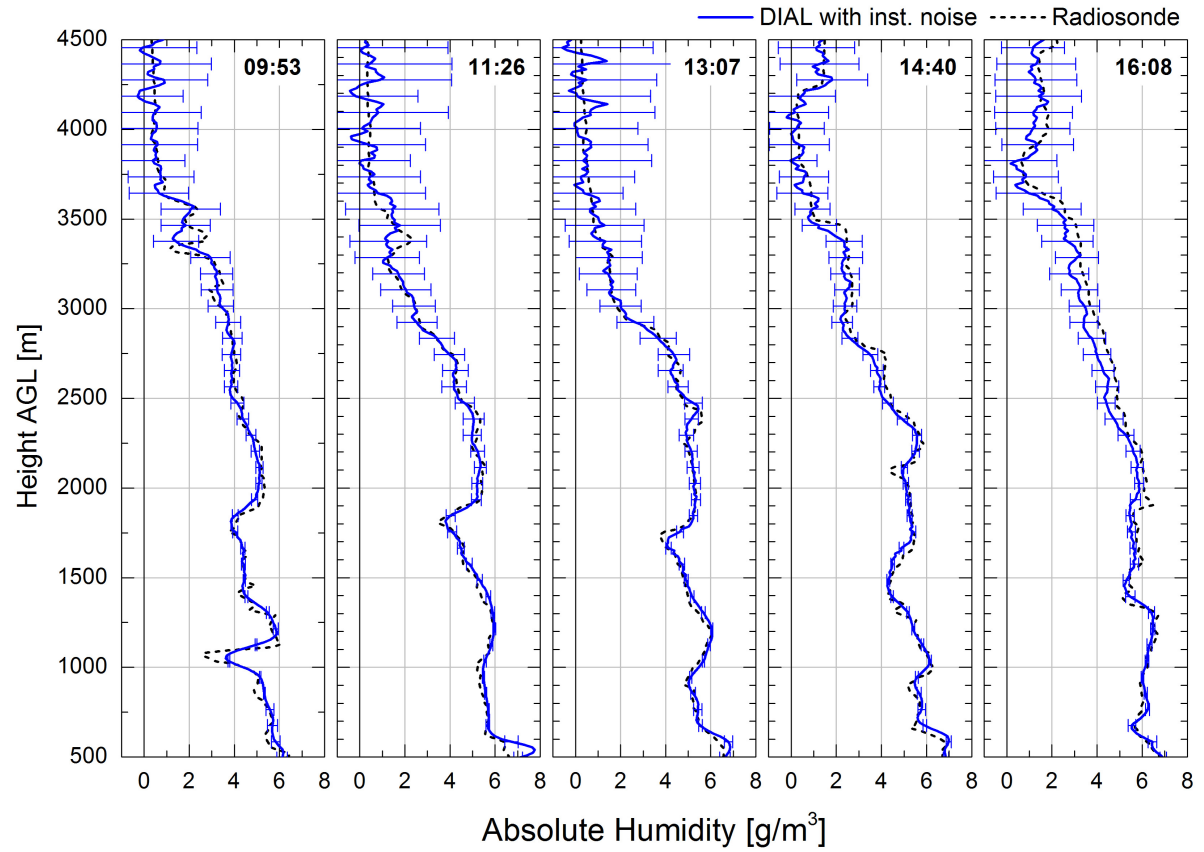

Figure 8. Intercomparisons between WV DIAL measurements and radiosonde profiles for five radiosonde launches on 3 October 2013 in Stuttgart-Hohenheim are shown. For the DIAL profiles, measurements of $20 \mathrm{~min}$ around the radiosonde launch times are averaged with a SaGo window range of $135 \mathrm{~m}$. With the DIAL profile, the instrumental noise errors were plotted as error bars. As radiosondes RS92-SGP of Vaisala were used.

\section{ACPD}

14, 29057-29099, 2014

High-resolution atmospheric water vapor measurements with a scanning DIAL

F. Späth et al.

Title Page

Abstract

Introduction

Conclusions

References

Tables

Figures

14

Back

Close

Full Screen / Esc

Printer-friendly Version

Interactive Discussion 

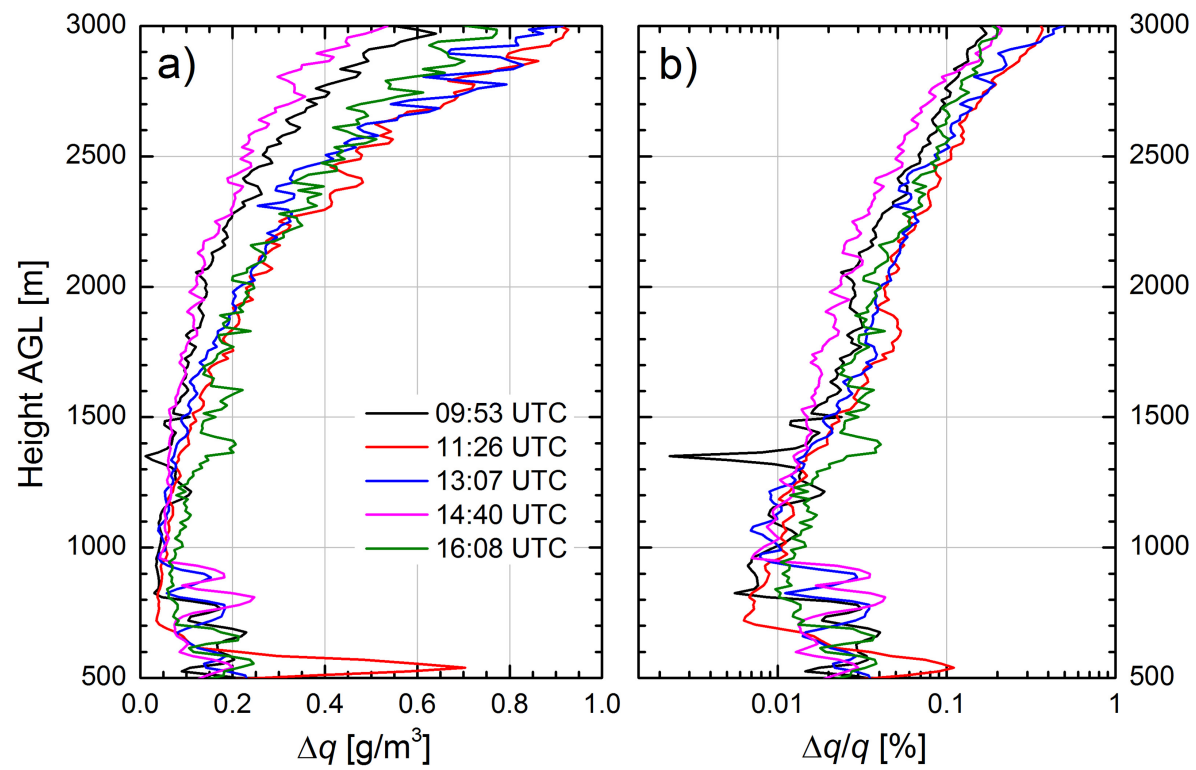

Figure 9. (a) Absolute instrumental noise error $\Delta q$ and (b) relative instrumental noise error $\Delta q / q$ determined from $20 \mathrm{~min}$ time averages around the radiosondes was plotted for heights between 0.5 and $3 \mathrm{~km}$.

\section{ACPD}

14, 29057-29099, 2014

High-resolution atmospheric water vapor measurements with a scanning DIAL

F. Späth et al.

Title Page

Abstract

Introduction

Conclusions

References

Tables

Figures

14

4

Back

Full Screen / Esc

Printer-friendly Version

Interactive Discussion 

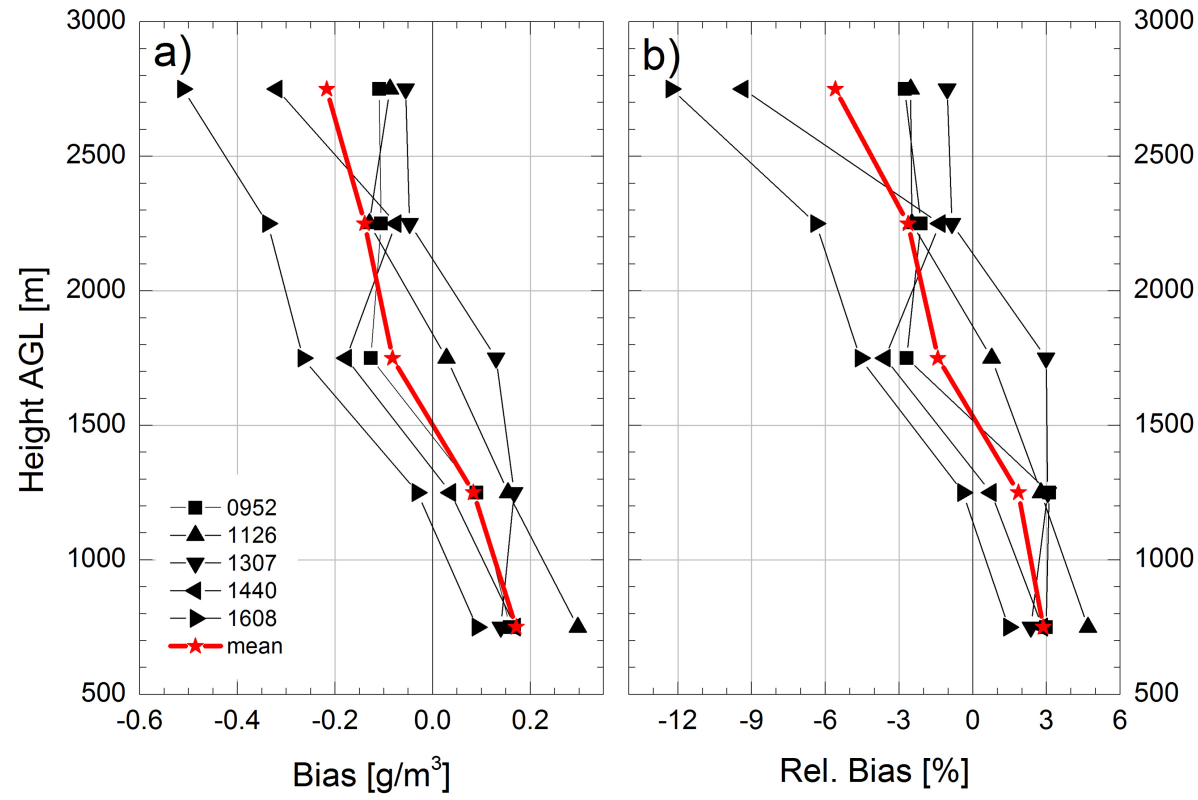

Figure 10. Bias in (a) absolute and (b) relative values in $500 \mathrm{~m}$ steps for five intercomparisons between WV DIAL and radiosonde profiles on 3 October 2013 are shown. In red the mean profiles were plotted.
ACPD

14, 29057-29099, 2014

High-resolution atmospheric water vapor measurements with a scanning DIAL

F. Späth et al.

Title Page

Abstract

Introduction

Conclusions

References

Tables

Figures

14

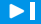

Back

Close

Full Screen / Esc

Printer-friendly Version

Interactive Discussion 


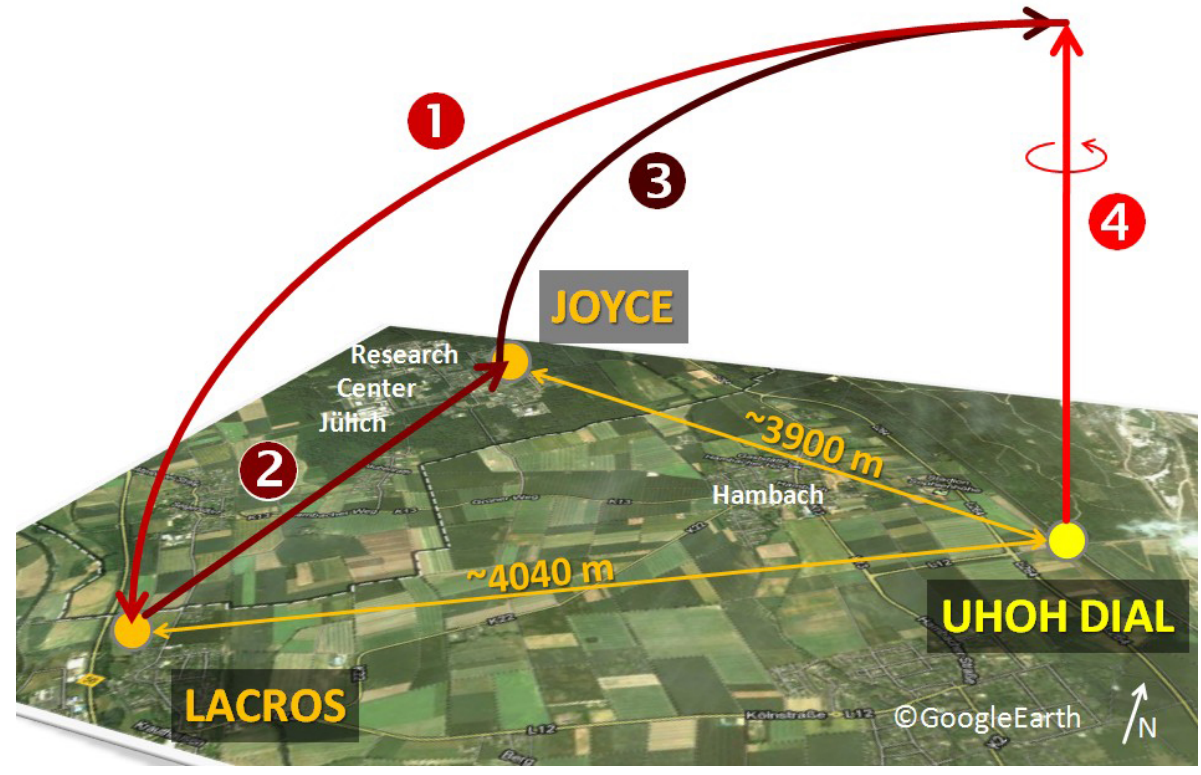

Figure 11. The map shows the measurement area and the arrangement of the HOPE supersites near Jülich, Western Germany. The arrows indicate the triangle scan pattern of the $\mathrm{UHOH}$ DIAL.
ACPD

14, 29057-29099, 2014

High-resolution atmospheric water vapor measurements with a scanning DIAL

F. Späth et al.

Title Page

Abstract

Introduction

Conclusions

References

Tables

Figures

14

4

Back

Close

Full Screen / Esc

Printer-friendly Version

Interactive Discussion 
a)

Range-Square corrected Partical Backscatter Signal @ 820nm, a.u.

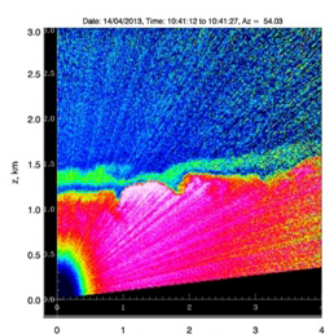

Hochonotal Panso. km

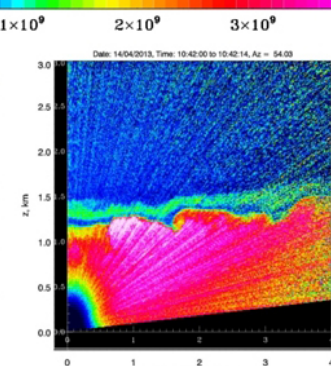

Hotronotue Aangoe, im
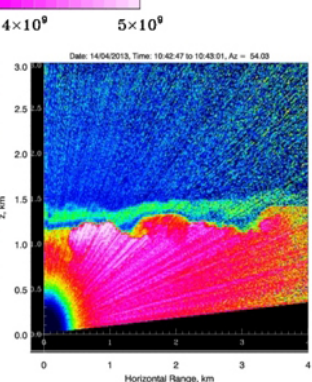

Hotronat Arove, im b)

Range-Square corrected Partical Backscatter Signal @ 820nm, a.u.
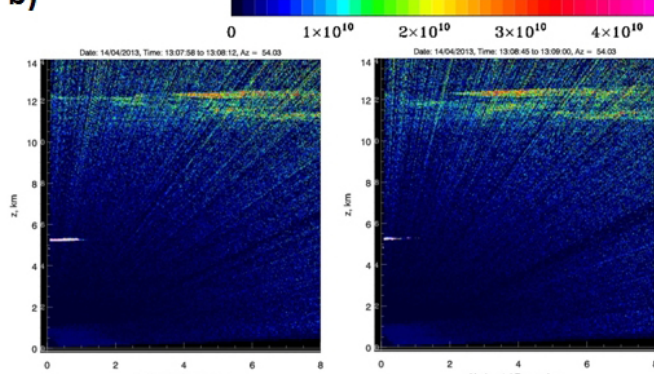

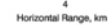

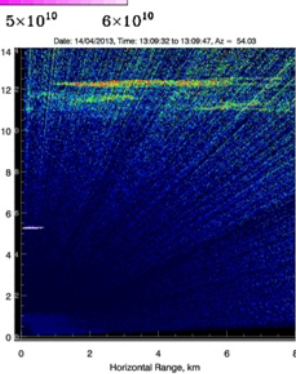

Figure 12. Measurement examples of fast $\mathrm{RHI}$ scanning measurements with a scan speed of $6^{\circ} \mathrm{s}^{-1}$ on 14 April 2013 at 10:41-10:43 UTC (top plots) and 13:07-13:09 UTC (lower plots). The plots show the range-corrected offline backscatter signal $\left(P_{\text {off }} r^{2}\right)$, each shot $(125 \mathrm{~Hz})$, range resolution $\Delta R=15 \mathrm{~m}$, in the direction of JOYCE. (a) The upper plots show the boundary layer in the range of $4 \mathrm{~km} \times 3 \mathrm{~km}$. One can see the wavy top and a second layer above the boundary layer. (b) In the lower panels a range of $14 \mathrm{~km} \times 8 \mathrm{~km}$ was plotted. There were some clouds above the DIAL at a height of $5 \mathrm{~km}$ and cirrus clouds at a height of $10-12 \mathrm{~km}$ were observed.

ACPD

14, 29057-29099, 2014

High-resolution

atmospheric water

vapor measurements

with a scanning DIAL

F. Späth et al.

Title Page

Abstract

Introduction

Conclusions

References

Tables

Figures

14

DI

4

Back

$>$

Close

Full Screen / Esc

Printer-friendly Version

Interactive Discussion 


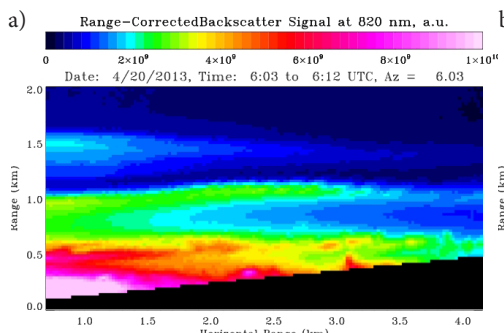

$\underset{\substack{2.0 \\ \text { Horizontal Range }(\mathrm{km})}}{2.5}$

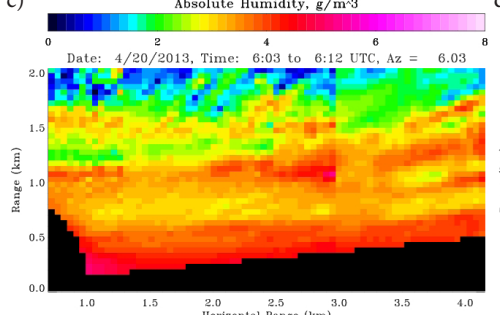

Horizontal Range $(\mathrm{km})$

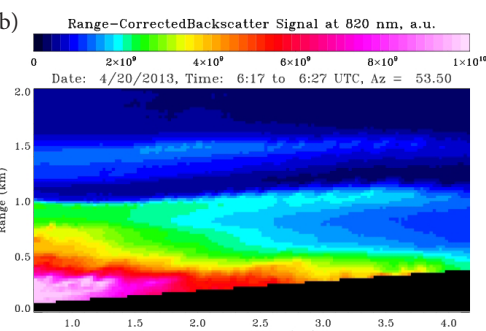

$\underset{\text { Horizontal Range }(\mathrm{km})}{2.0}$

d)

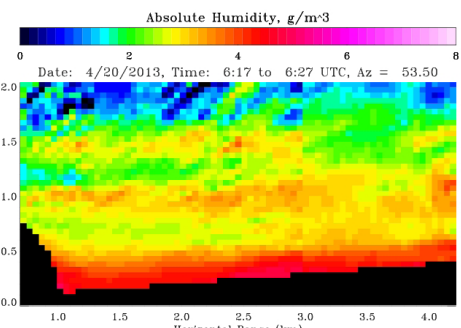

Figure 13. Measurement examples from 20 April 2013 of two slow scanning measurements between 06:03 and 06:27 UTC with a temporal resolution $\Delta t$ of $10 \mathrm{~s}$. (a) and (c) shows the direction of LACROS and (b) and (d) the direction of JOYCE in the distance range of $700 \mathrm{~m}$ to $4.2 \mathrm{~km}$. (a) and (b) are range-corrected backscatter signals $\left(P_{\text {off }} r^{2}\right)$ and (c) and (d) are absolute humidity. The scanning $P_{\text {off }} r^{2}$ data are gridded to a horizontal and vertical grid resolutions of $25 \mathrm{~m}$, the absolute humidity has a grid resolution of $50 \mathrm{~m}$ with different SaGo window lengths $\Delta R$ depending on the distance to the lidar. The scan was driven in (a) and (c) from vertical to low elevation of $5^{\circ}$ and in (b) and (d) vice versa (Fig. 11).

ACPD

14, 29057-29099, 2014

High-resolution atmospheric water vapor measurements with a scanning DIAL

F. Späth et al.

Title Page

Abstract

Introduction

Conclusions

References

Tables

Figures

14

$\Delta$

4

Back

$>$

Close

Printer-friendly Version

Interactive Discussion 